This PDF is a selection from an out-of-print volume from the National Bureau of Economic Research

Volume Title: Capital Flows and the Emerging Economies: Theory, Evidence, and Controversies

Volume Author/Editor: Sebastian Edwards, editor

Volume Publisher: University of Chicago Press

Volume ISBN: 0-226-18470-6

Volume URL: http://www.nber.org/books/edwa00-1

Conference Date: February 20-21, 1998

Publication Date: January 2000

Chapter Title: Capital Flows and the Behavior of Emerging Market Equity Returns

Chapter Authors: Geert Bekaert, Campbell R. Harvey

Chapter URL: http://www.nber.org/chapters/c6168

Chapter pages in book: (p. 159 - 194) 


\title{
Capital Flows and the Behavior of Emerging Market Equity Returns
}

\author{
Geert Bekaert and Campbell R. Harvey
}

\subsection{Introduction}

During the last decade, we have witnessed significant changes in the pattern of world capital flows with some of the most dramatic changes taking place in emerging markets. In the late 1980s and early 1990s, a number of developing economies initiated reforms to liberalize their capital markets. These reforms made it easier both for foreign investors to access the local market and for domestic investors to diversify their portfolios internationally. Foreign equity and bond purchases have become an increasingly important source of capital for developing countries.

The recent crises in Asia and in Mexico in 1994 emphasize the importance of understanding both the impact of capital market liberalizations and the role of foreign portfolio flows for a country's economic prospects. The views widely differ. On the one hand, there is a new stream of research that examines the role of the financial sector and economic growth prospects. King and Levine (1993a, 1993b), Levine and Zervos (1996), Rajan and Zingales (1997), and Bekaert and Harvey (1998) all find a positive relation between the development of the financial sector and economic growth. Obstfeld (1994) explicitly links financial market integration to economic growth. Moreover, Bartolini and Drazen (1996) describe free

Geert Bekaert is professor of finance at Columbia Business School, on leave from Stanford University's Graduate School of Business, and a research associate of the National Bureau of Economic Research. Campbell R. Harvey is the J. Paul Sticht Professor of International Business at Duke University's Fuqua School of Business and a research associate of the National Bureau of Economic Research.

The authors appreciate the suggestions of Sebastian Edwards and the comments of conference participants. The authors thank Andrew Roper and Diego Valderrama for their helpful research assistance. 
capital mobility as a possible signal for the government to use to enhance the credibility of a broader reform program. On the other hand, Krugman (1993) is skeptical about the benefits of capital market liberalizations and Mathieson and Rojaz-Suarez (1992) describe how an open capital account may undermine structural reform programs. Worse, some have argued that "the integration of financial markets is dangerous and destabilizing."

Our goal is to characterize the relation between U.S. equity flows to emerging markets and important financial and macroeconomic variables. We use data on net U.S. equity capital flows to seventeen emerging markets during 1977-96. Following Bekaert, Harvey, and Lumsdaine (1999), we identify the break point in net equity capital flows (either up or down). We view these break points as indicative of the date when the marginal investor may have changed from local to foreign or vice versa. With these dates, we examine the behavior of a wide variety of economic and financial indicators.

We examine four categories of indicators. The first group includes the cost of capital, correlation with the world market return, and volatility. The second group focuses on the structure of the market. We include indicators such as the asset concentration ratios, the size of the market, and liquidity indicators. The third category is the economy: Foreign exchange volatility, real exchange rates, real gross domestic product (GDP) per capita, the size of the trade sector, inflation, interest rates, and fiscal deficits are analyzed. The last category is country risk. We are interested in the international perceptions of political, economic, and financial (credit) risk before and after changes in capital flows.

It is important to remember that capital flows are endogenous. Generally speaking, they should be considered the endogenous outcome of a portfolio choice problem. While we report statistics based on pre- and post-capital-flow break points, at no point do we argue that increases in net capital flows "cause" changes in any of these indicators. The complex process of liberalization provides the foundation for increases in capital flows. It is likely that the components of this process account for the changes in the variables that we report. ${ }^{2}$

Our exploratory analysis remains useful in light of the many financial and economic woes ascribed to foreign investors by concerned policy makers. The nature of our exercise prevents us from testing formal hypotheses, but our results may guide future empirical and theoretical work. In addition, our results may cast doubt on some popular rhetoric regarding the implications of foreign capital inflows.

1. See "Capital goes global," Economist, 25 October 1997, pp. 87-88. Claessens, Dooley, and Warner (1993) examine whether one can distinguish "hot," speculative capital flows from long-run, stable flows.

2. See Bohn and Tesar (1996), Calvo and Mendoza (chap. 1 in this volume), and Bacchetta and van Wincoop (chap. 3 in this volume) for alternative models of capital flows. 
The paper is organized as follows. Section 6.2 provides the setting for our investigation by describing the relation between capital flows and financial market integration. Section 6.3 provides a brief description of the capital flow data that we use and some summary statistics. In this section, we describe our calculation of the break points. Section 6.4 details the behavior of the returns, financial structure, economy, country risk, and liquidity around capital flow breaks. Some concluding remarks are offered in the final section.

\subsection{Capital Flows and Financial Market Integration}

It is useful to distinguish between economic integration and financial integration. Economic integration is associated with the reduction in trade barriers (see Sachs and Warner 1995 for an extensive survey). Financial integration is associated with barriers to portfolio investments. It is often the case that these two concepts are linked. Indeed, Bekaert and Harvey (1995) use the size of the trade sector as an instrument for financial integration. While our focus is on financial integration, we will track the behavior of the trade sector to investigate whether financial integration coincides with economic integration in our sample.

A market is financially integrated if a project with identical risk has identical expected returns across different markets. The opposite of market integration, market segmentation, can cause fundamental distortions in an economy. In the segmented market, local investors are restricted to investing in local securities and foreign investors are not allowed (or the cost is high) to invest in the local market.

Obstfeld (1994) and Stulz (1999) detail some of the distortions that occur in the segmented market. Local investors are unable to diversify their equity portfolios because they can only invest in local securities. Further, the local market is usually very small with only a small number of securities. Since investors will pay a premium for diversification, new local firms will arise that inefficiently operate in industries that provide diversification. Current firms may also diversify away from their core activities by accepting negative net present value projects that make them more attractive to investors. One can see that segmentation directly leads to an inefficient allocation of productive resources.

The process of integration should reverse these inefficiencies. Investors will no longer be interested in investing in inefficient domestic companies when they can purchase a foreign stock that is efficient. If the economic liberalization occurs at the same time, the inefficient companies will likely be driven out of business because of price and quality competition from foreign producers. Similarly, the current producers in the local economy may reallocate capital from the inefficient conglomerate divisions to the divisions that have a comparative advantage. Nevertheless, Bekaert and 
Harvey $(1995,1997,2000)$ argue that it is particularly difficult to pin down the exact date when the local market becomes integrated with world markets. Using the legislative dates of capital market liberalizations is fraught with danger. For example, a country might initiate widespread reformsbut foreign investors ignore the country's equities because of market imperfections, because the reforms are incomplete, or because they deem the reform program not credible. Hence, while technically open, the market is effectively segmented.

The patterns in net capital flows should reveal much information about market integration. After legal reforms are initiated and the market structure is satisfactory - that is, if the market becomes truly integrated - we should see an increase in capital flows. It is also possible that the market moves in the other direction, that is, toward segmentation. If restrictive measures are initiated or the political and economic environment is not conducive to international investors, capital flows should "dry up." It is therefore also important to carefully consider the particular economic and political environments within each country. We have formed chronologies of important events that might impact capital flows for twenty countries. The timelines for each country are available at www.duke.edu/ charvey/ Country_risk/couindex.htm.

Our investigation does not address the question of whether a developing country should prefer direct investment flows to portfolio flows. We choose to concentrate on the portfolio flows, more particularly on equity flows. However, we can indirectly shed some light on this question. It is popularly believed that since portfolio investment is more mobile than direct investment, increased portfolio investment could destabilize an economy and its financial markets. This leads us directly to our investigation of capital flows and equity returns. Destabilization might manifest itself through increased equity volatility. Early work by Bekaert (1995), Tesar and Werner (1995a), and Bekaert and Harvey (1997) suggests that this is not the case, but the results in Bekaert and Harvey (2000) are more mixed. We reassess these results and expand the scope of examination to other sensitive measures such as foreign exchange volatility and turnover.

The behavior of equity returns also includes any change in the cost of equity capital. Clark and Berko (1997) find that surprise purchases of Mexican equity lead to a significant and substantial price rise. They conclude that the price rise is permanent, reflecting greater risk sharing and improved liquidity, and hence induces a reduction in the cost of equity capital. Similarly, Henry (2000) documents a substantial positive price response to capital market liberalizations. Following Bekaert and Harvey (2000), we argue that the dividend yield is directly related to the cost of capital. We find that the dividend yield is sharply lower after increases in capital flows. Even if the change constitutes an actual change in the cost of capital, it is important to realize that foreign investment may not be the only causal factor. For example, Henry (2000) ascribes 50 percent of the 
price response to macroeconomic reforms (which may affect the growth rate of dividends as well), but Bekaert and Harvey (2000) find that an important part of the total drop in the dividend yield is accounted for by capital market liberalizations. We also find that correlations with the world market return are doubled after capital flow breaks. A decrease in expected returns and an increase in correlations suggests that the process of market integration leads to reduced diversification benefits for international investors, confirming the results in Bekaert and Urias (1996).

The rest of our paper details the association of capital flow breaks with financial and economic fundamental variables. We find that there are changes in almost every measure we examine moving from a low capital flows period to a high capital flows period.

Our focus on equity flows is potentially quite restrictive. Equity capital may flow into an emerging market while bond flows are drying up. After a general market opening, of course, we expect both bond and equity flows to increase more or less simultaneously as foreign investors adjust their portfolios. We therefore obtained data on bond flows and examine how they correlate with equity flows.

\subsection{Capital Flows Data}

\subsubsection{World Capital Flows}

The ideal data for the study of capital flows is a monthly world matrix of flows. Each element would detail the net flow from (row) a country to (column) another country. However, the task of constructing such a matrix is extraordinarily difficult. First, the United States is one of the few countries that has detailed monthly measurements for sixty-five countries. Even the United Kingdom, a country with bountiful economic data, does not report flows to individual countries. Second, even if two countries report flows, they are not easily reconciled because of different collection conventions. For example, Tesar and Werner (1994) do some basic cross-checking of U.S. treasury and Canadian data and find that the average quarterly net purchases of U.S. shares reported by Statistics Canada is less than half of those reported by the U.S. Treasury, while no similar magnitude of discrepancy is found for the reported U.S. net purchases of Canadian equity. Third, the country of origin is not necessarily the final destination for the capital flows. For example, much of the flow to the United Kingdom is channeled to other European and world investments because London is the leading world clearinghouse for non-U.S. transactions. ${ }^{3}$

Some attempts have been made to reconcile and create a flow matrix.

3. Similar problems exist for measuring bond flows. Ito (chap. 8 in this volume) reports that bank lending both in Asia and Latin America is dominated by European banks, not U.S. banks. 
Indeed, there is great practitioner interest in this exercise. Empirical evidence from U.S. data on stock inclusions in a major index (Shleifer 1986; Harris and Gurel 1986) or flows to mutual funds (Warther 1995) suggests that flows affect prices. Presumably a superior measure of flow could lead to excess profits in the context of a trading strategy. Howell (1993) and Howell and Cozzini $(1991,1992)$ undertake the construction of a capital flow matrix.

We have obtained the Howell matrices for the years 1986-92. ${ }^{4}$ Unfortunately, these matrices are only prepared on an annual basis. Furthermore, emerging markets are coarsely organized into three categories: Latin America, Asia, and other. Finally, many of the liberalizations were taking place in the early 1990s and these data end in 1992.

The Howell data, however, can give some insight into what we are missing by focusing on purely U.S. Treasury data. For example, in 1992 the total net equity flows to emerging markets was US\$15.95 billion as reported in Howell. Of that amount, $\$ 8.97$ billion originated from the United States. The next most important country is the United Kingdom, with $\$ 2.85$ billion in flows (some of which is probably U.S. originated). The Department of Treasury (DOT) data suggest that the U.S. equity flows to emerging markets in 1992 were $\$ 5.54$ billion. This comparison suggests that the Treasury data capture a sizable portion of the flows to emerging markets.

\subsubsection{U.S. Capital Flows}

Tesar and Werner (1994) provide a detailed analysis of the components of the U.S. capital flows data. The U.S. international portfolio investment transactions are reported through the DOT's International Capital Form S. Operationally, the twelve district Federal Reserve Banks, principally the Federal Reserve Bank of New York, collect these data, maintain contact with the respondents, and ensure the accuracy and integrity of the data (Kester et al. 1994). Tabulation of the data, however, is done by the DOT and is presented in its Quarterly Bulletin. The reporting is done on a monthly basis.

By law, banks, brokers, dealers, other financial institutions, and individuals are required to report the value of any long-term security transaction involving a foreign resident. American depositary receipt (ADR) transactions are included in the figures. Securities transactions are reported on a transaction basis. They are recorded by the nationality of the person with whom you are carrying out the transaction, not by the country that originally issued the security. A foreigner is any individual, branch, partnership, association, corporation, or other organization located outside the United States. Additionally, securities are recorded according to the residency of the issuer and not their currency denomination.

4. We are grateful to Michael Howell for providing us with this information. 
Exceptions for reporting are given when the total purchases and the total sales of securities are less than $\$ 2$ million for the reporting month. There are penalties for failing to report that can result in a civil penalty of up to $\$ 10,000$ and up to a year in prison for willful failure to report (see DOT International Capital Form S).

As mentioned earlier, there are several problems with the data. The increasing complexity of financial transactions and the development of new financial instruments makes it harder to record all the appropriate information. Kester et al. (1994) detail three potential problems related to the reporting procedures themselves. These problems involve recording of information of U.S. residents living abroad, financial transactions carried out in foreign financial centers, and stocks of securities held by U.S. residents that are classified geographically by the counterparty and not by the issuing country.

Our data come directly from the DOT's Quarterly Bulletin, table CMV-4, "Foreign Purchases and Sales of Long-Term Securities by Type and Country." This table reports "Gross purchases by foreigners," which we classify as a U.S. sale, and "Gross sales by foreigners," which we classify as a U.S. purchase. We focus on foreign equity securities (columns 7 and 14) and bond securities (columns 6 and 13).

\subsubsection{Accumulating Capital Flows and Break Points}

The capital flow data have been extensively studied before in a portfolio allocation context by Bohn and Tesar (1996) and Tesar and Werner (1994, 1995a, 1995b). We begin by accumulating the capital flows to obtain an approximate measure of the ratio of U.S. ownership to market capitalization. This process must include local market equity appreciation realized by the U.S. investor. The dollar position of U.S. investors in emerging equity market $i$ is

$$
\text { Ownership }_{i, t}=\text { Flow }_{i, t}+\text { Ownership }_{i, t-1}\left(1+R_{i, t}\right),
$$

where Flow is the net capital flow in period $t$ and $R_{i, t}$ is the market $i$ return in U.S.-dollar terms from the International Finance Corporation (IFC). ${ }^{5}$ We also calculate the cumulative net capital bond flows. Since we do not have information on bond returns in each market, we present a simple accumulation of the net bond flows. While our statistical analysis concentrates on equity ownership using equation (1), figure 6.1 presents the simple accumulation of equity and bond flows. The correlations that are reported in the figure are also based on the simple accumulations.

5. Tesar and Werner (1995a) do not take into account the capital gains on the equity investments for emerging markets. They report a simple accumulation of the net capital flows. However, Tesar and Werner (1994) do adjust for capital gains. 

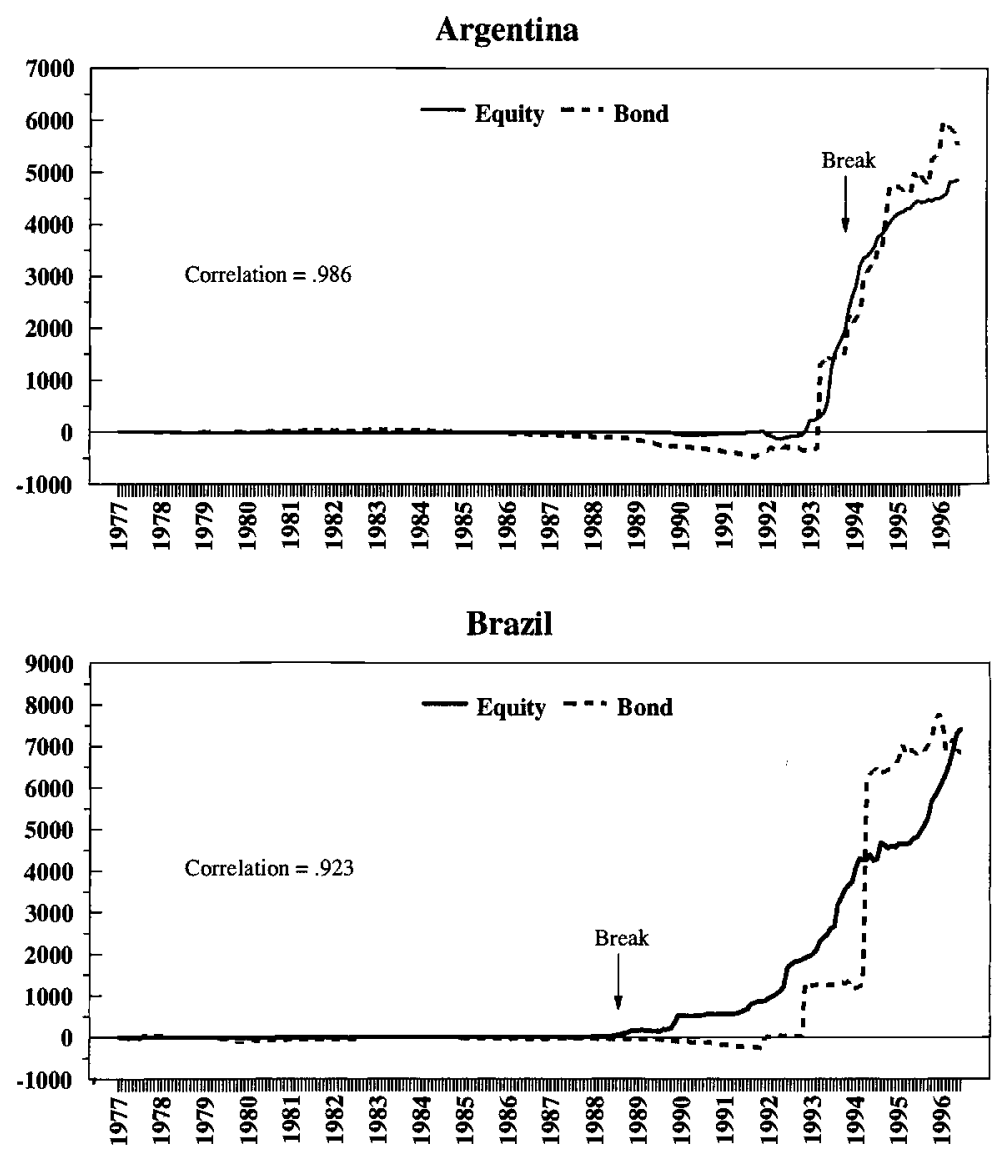

Chile

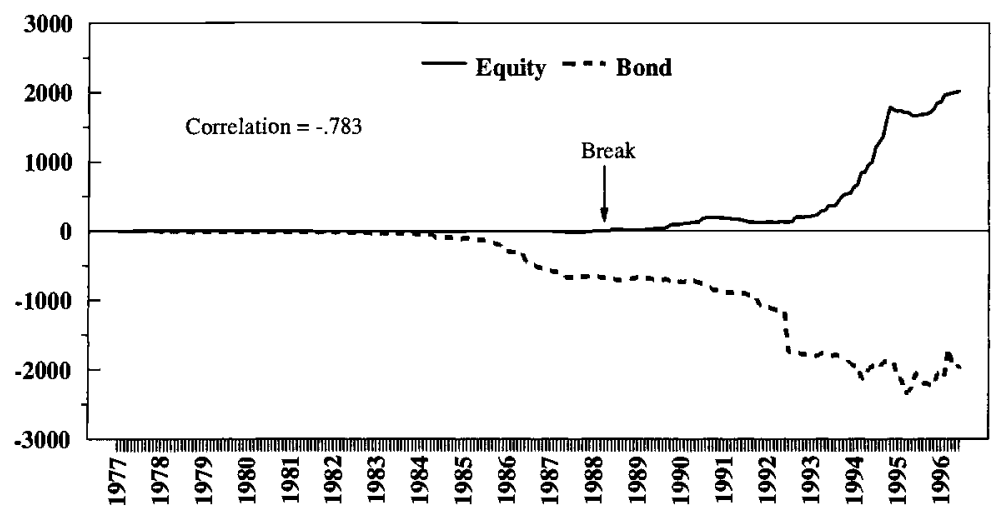

Fig. 6.1 Cumulative U.S. net equity and bond flows for seventeen emerging markets

Note: US\$ millions unadjusted for local returns. Equity breaks based on flows adjusted for market returns divided by market capitalization. 


\section{Colombia}

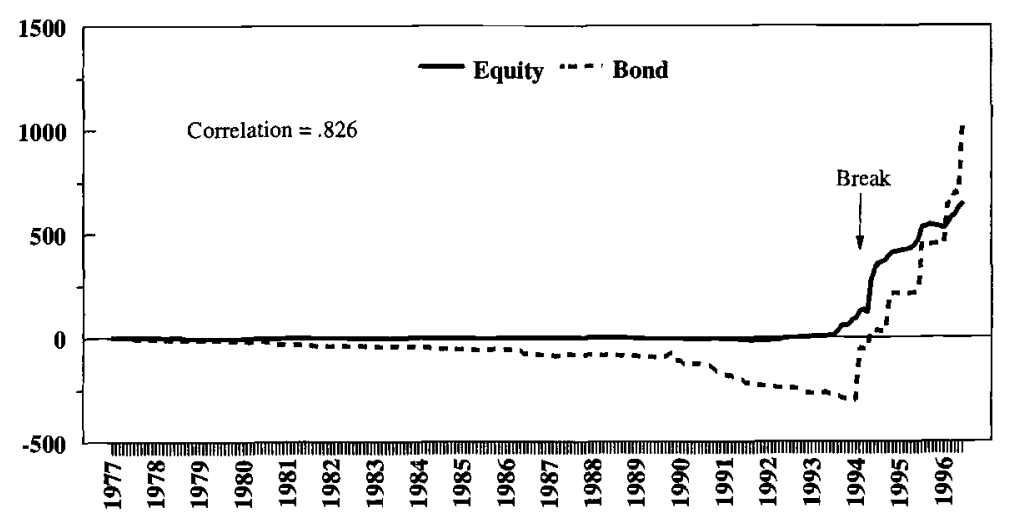

\section{Greece}

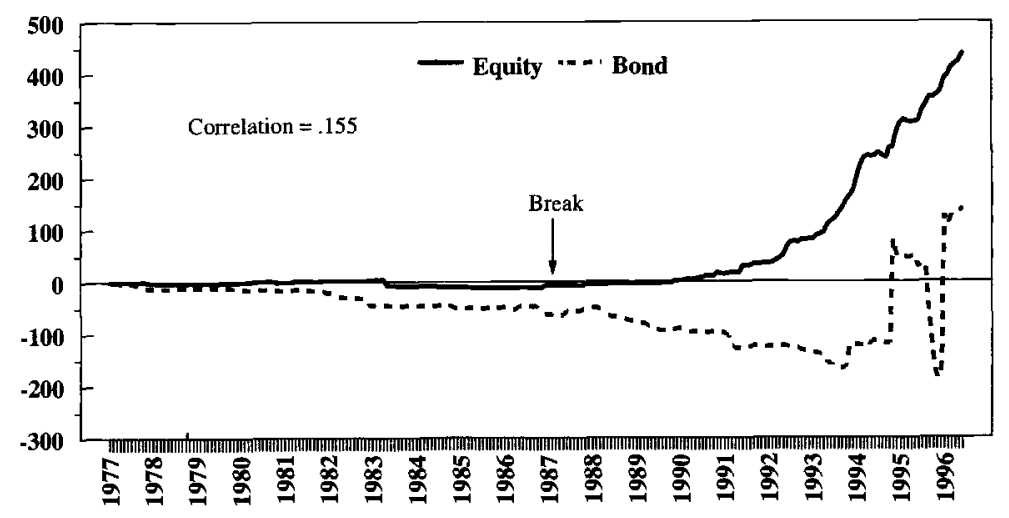

\section{India}

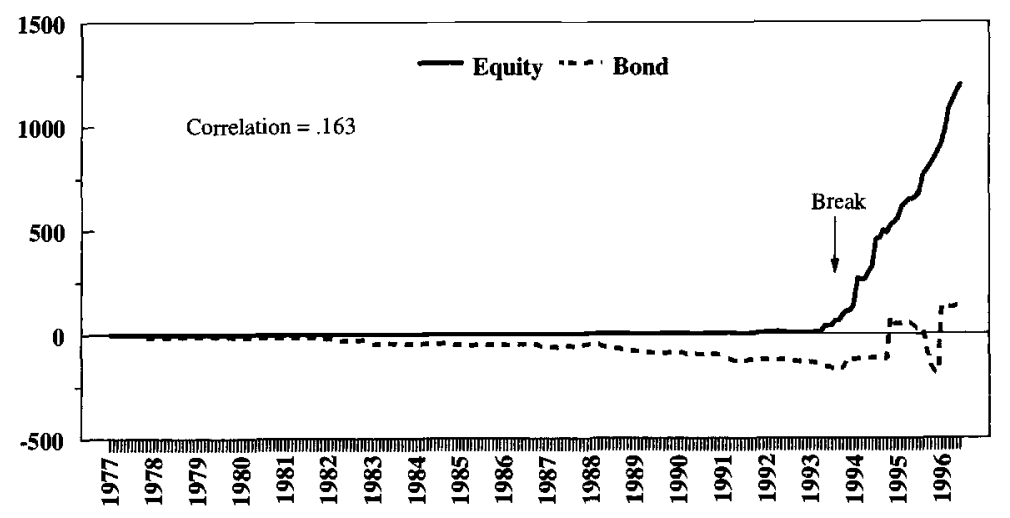

Fig. 6.1 (cont.) 


\section{Indonesia}

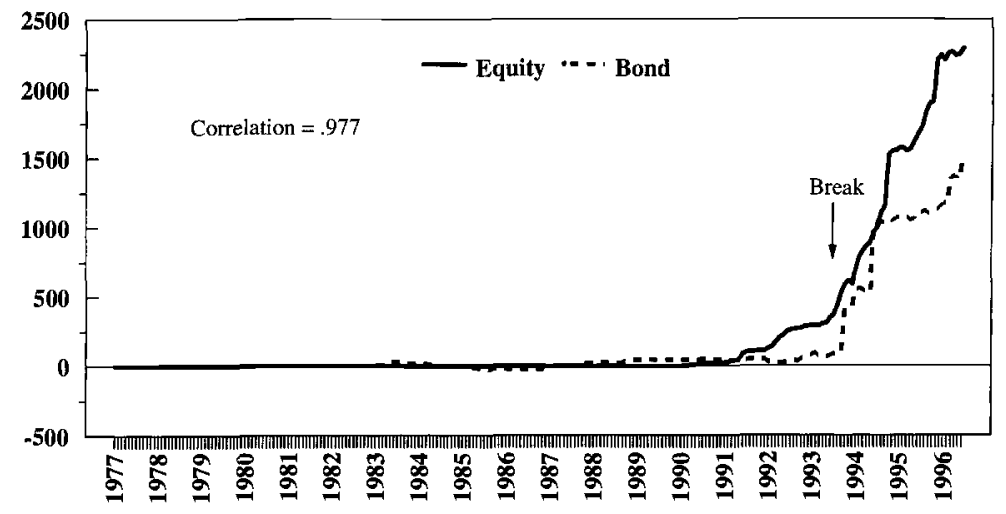

Korea
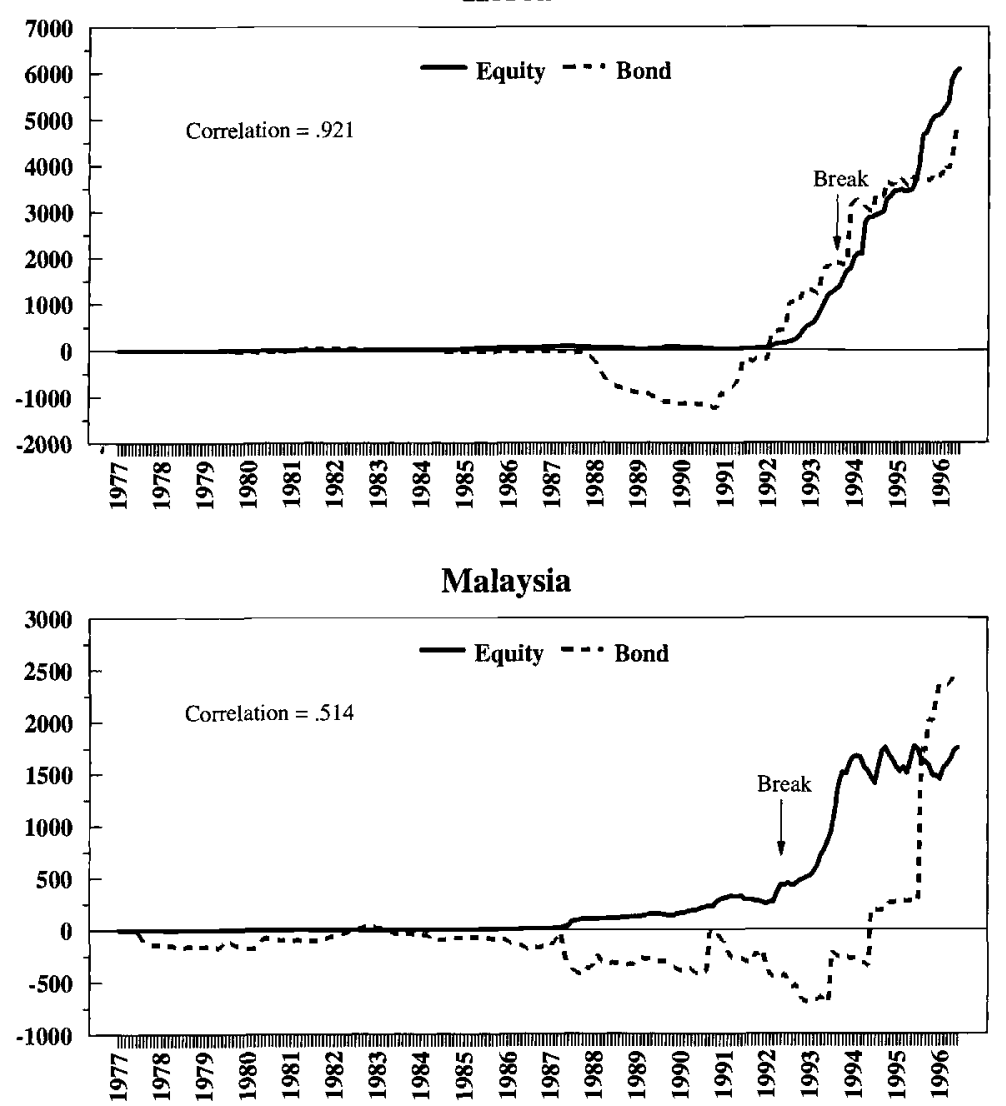

Fig. 6.1 (cont.) 


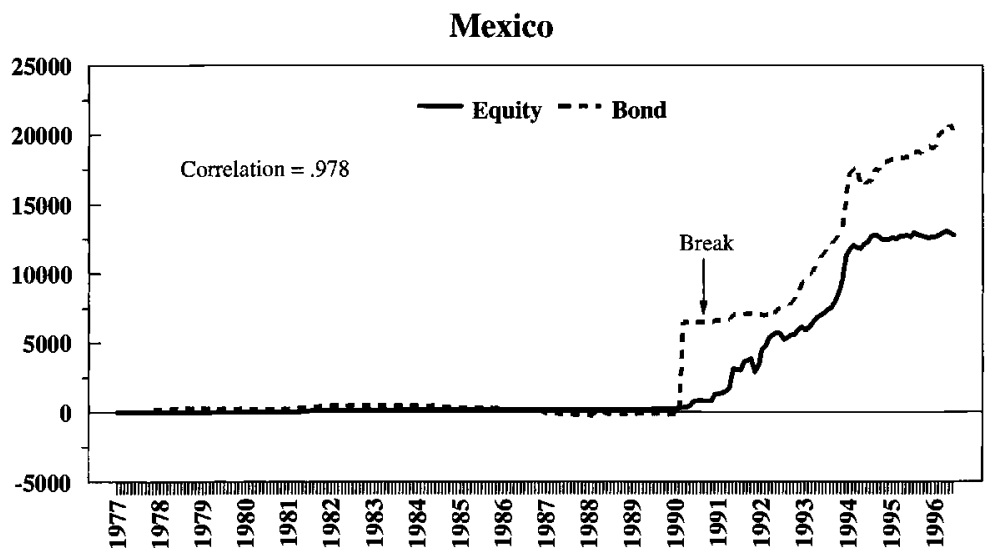

Pakistan

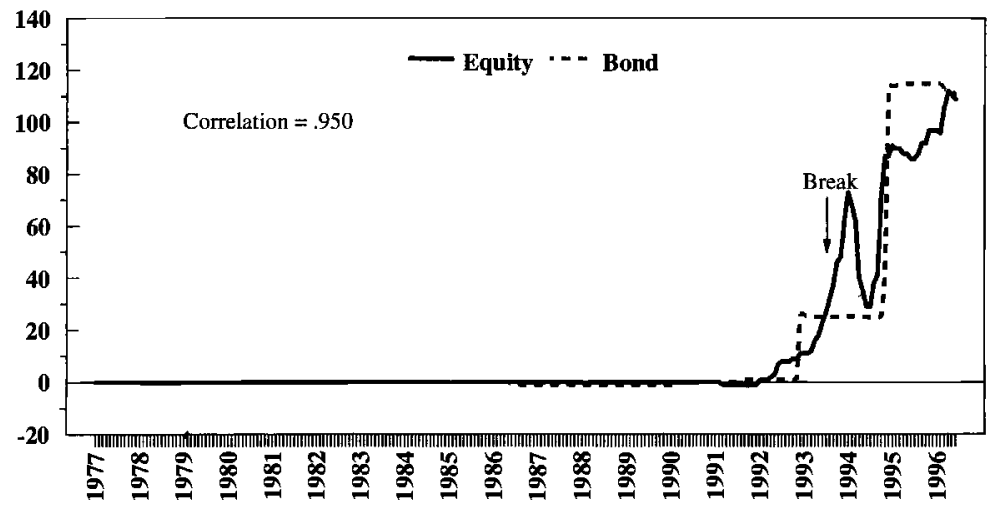

Philippines

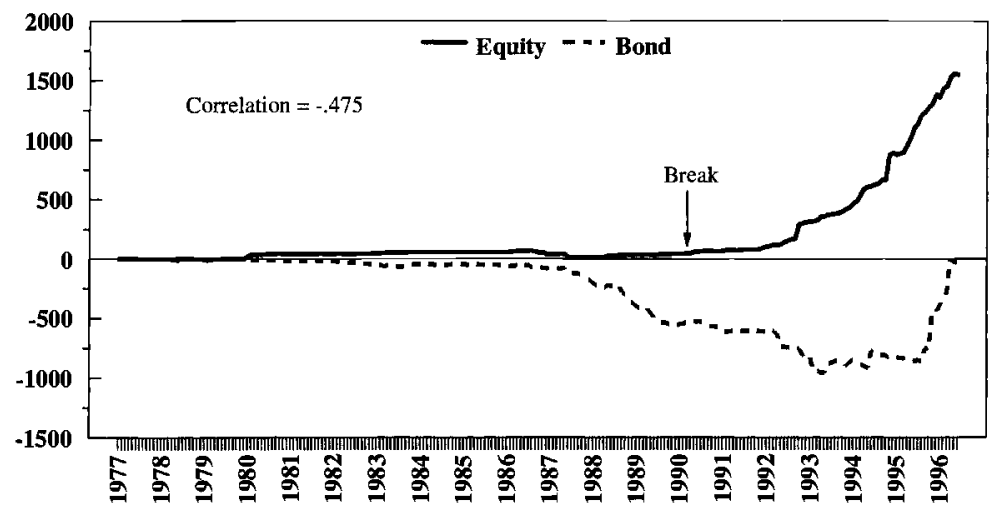

Fig. 6.1 (cont.) 

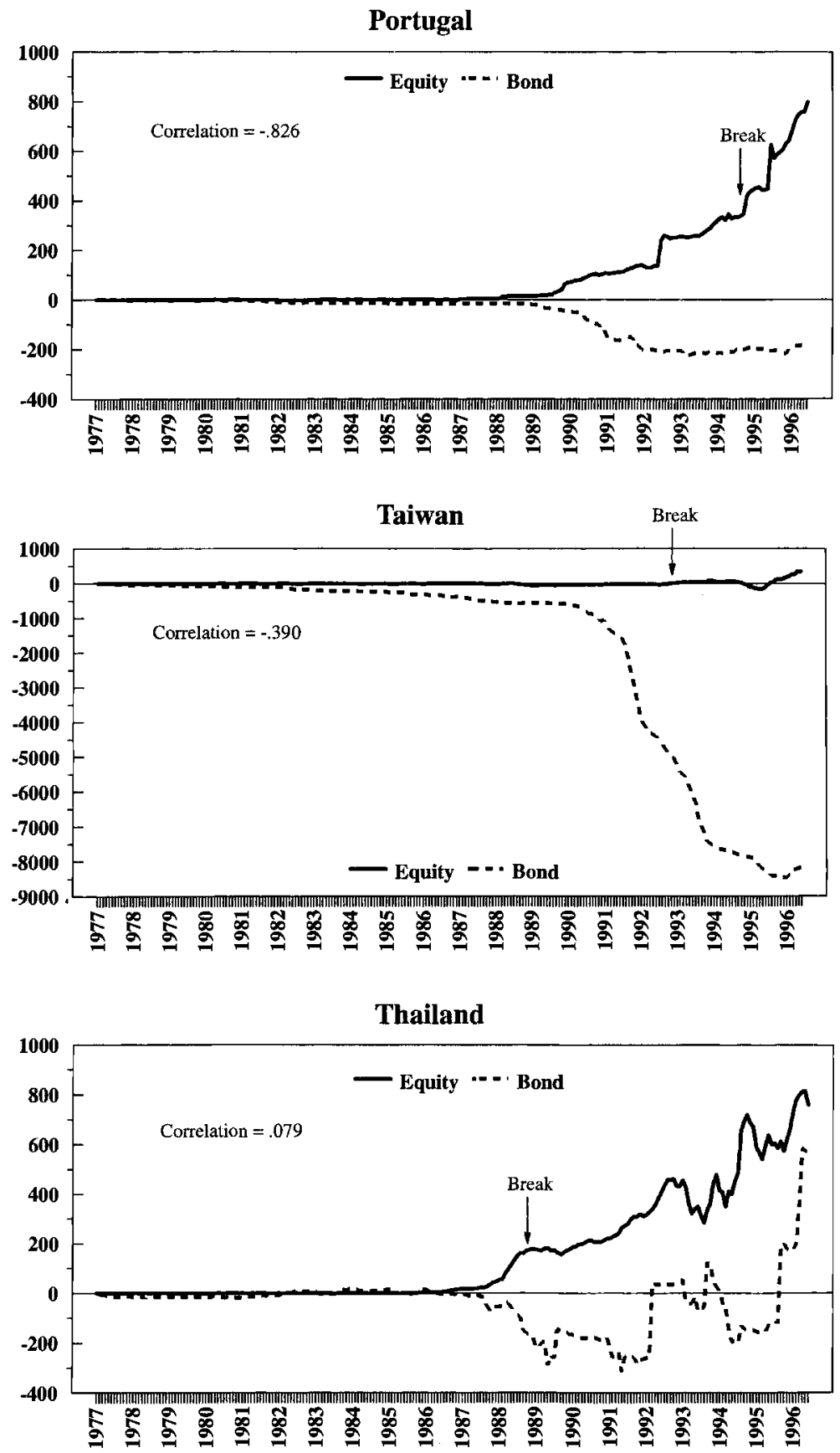

Fig. 6.1 (cont.) 

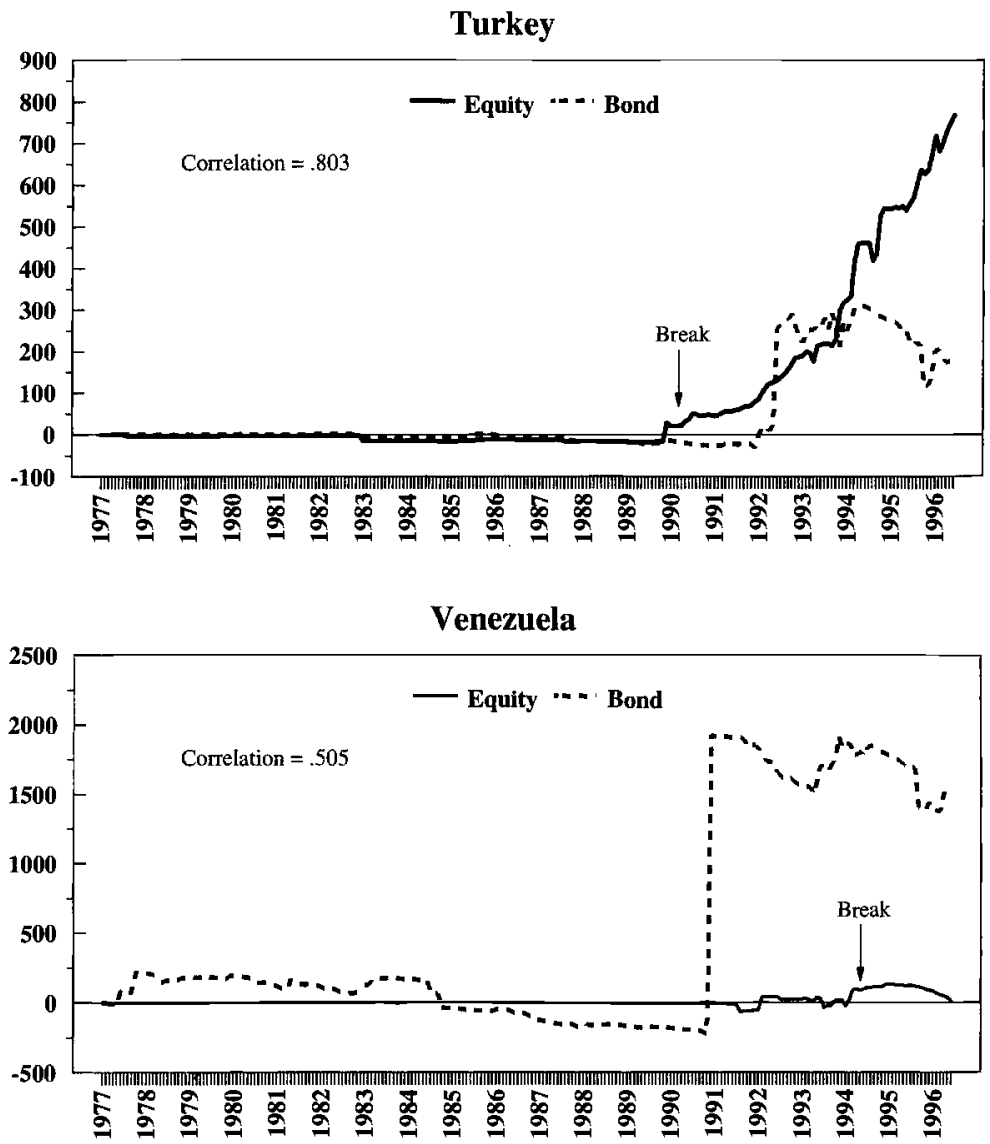

Fig. 6.1 (cont.)

One problem that we face is the starting point. The capital flow data from the DOT's Quarterly Bulletin begins reporting in January 1977. However, for many countries there are zero entries for a number of years. In addition, we rely on the IFC data to calculate the increase in equity ownership resulting from a rise in the local market index. Hence, the starting point for equation (1) differs across many countries. Further, we do not know the initial stock of U.S. capital in the emerging stock market. Hence, it is possible that we calculate some of the early ownerships as small negative numbers. The negative ownerships do not concern us too much given the nature of our examination. Our focus is on the more recent flow data. In addition, we are concerned with the patterns in the flows - not the levels. Finally, it also may be the case that foreigners hold portfolios different than the IFC index. Kang and Stulz (1997) show that foreign investors are 
more likely to invest in securities that are large and well known. The IFC indices have some advantage here over more comprehensive local indices because of the IFC's focus on large, relatively liquid securities.

Our first task is to assess the break points in the equity flows. We use the break points that are reported in Bekaert and Harvey (2000). We examine seventeen emerging markets that are tracked by the IFC. The IFC also tracks Jordan, Nigeria, and Zimbabwe; however, the Treasury Bulletin does not include data on these countries. ${ }^{6}$

We use the endogenous break point tests detailed in Bai, Lumsdaine, and Stock (1998). We report the 90 percent confidence interval for the break as well as the median point. In some countries, for example Taiwan, there is a wide confidence interval. In other countries, for example the Philippines, the interval is extremely tight. The technique tells us whether there is a break in the time series-but it does not tell us if the break is up or down. A visual inspection of the data suggests that sixteen of the seventeen are associated with increases in capital flows and only one, the Philippines, is associated with a decrease in capital flows.

Table 6.1 also reports the mean levels of ownership five years before and five years after (and including the break month). For some of the countries, we do not have data for five years after. We then report the average to the end of the sample. Table 6.1 confirms that foreign ownership is greater in the postbreak period for every country except the Philippines. It may be the case that foreign equity ownership is increased at the expense of foreign bond ownership. However, this does not necessarily appear to be the case. Table 6.1 reports the mean levels of cumulative bond flows before and after the equity break. In eleven of the sixteen countries, the bond flows increase (often sharply) after the equity break.

We report four types of test statistics over two different samples. In the first sample, the Philippines (the only country where the capital flows break in a downward direction) is excluded. In the second sample, all countries with insignificant breaks, from the first column of table 6.1, are excluded. The first statistic is a simple difference in means across the seventeen countries. This test allows for different variances in the prebreak and postbreak data, but imposes independence across countries and across time.

The second set of tests is country specific. We conduct heteroskedasticity-consistent tests of the hypothesis of no change in each time series for each country. These tests also correct for a first-order moving average process in the residuals for all series that are available on a monthly basis. For those series that have components that are observed at an annual

6. The IFC currently follows more than twenty markets. We use the full sample of countries that are available in 1992. Our statistical tests require a minimum number of observations. As a result, we do not include Eastern European countries and others that were added after 1992. 


\begin{tabular}{|c|c|c|c|c|c|c|c|c|c|}
\hline \multirow[b]{3}{*}{ Country } & \multicolumn{3}{|c|}{$\begin{array}{l}\text { Net Equity Holdings } \\
\text { Break Point }\end{array}$} & \multicolumn{2}{|c|}{$\begin{array}{l}\text { Level of } \\
\text { Equity Holdings }\end{array}$} & \multicolumn{2}{|c|}{$\begin{array}{c}\text { Cumulative } \\
\text { Net Bond Flows }\end{array}$} & \multirow{2}{*}{\multicolumn{2}{|c|}{$\begin{array}{l}\text { Correlation of } \\
\text { Equity and Bond } \\
\text { Flows }\end{array}$}} \\
\hline & & & Ninety- & Five & Five & Five & Five & & \\
\hline & $\begin{array}{c}\text { Fifth } \\
\text { Percentile }\end{array}$ & Median & $\begin{array}{c}\text { fifth } \\
\text { Percentile }\end{array}$ & $\begin{array}{l}\text { Years } \\
\text { Before }\end{array}$ & $\begin{array}{l}\text { Years } \\
\text { After }^{\mathrm{a}}\end{array}$ & $\begin{array}{c}\text { Years } \\
\text { Before }\end{array}$ & $\begin{array}{l}\text { Years } \\
\text { After }^{\text {A }}\end{array}$ & $\begin{array}{c}\text { Full } \\
\text { Sample }\end{array}$ & $\begin{array}{l}\text { Post- } \\
1990\end{array}$ \\
\hline Argentina & Apr-93 & May-93*** & Jun-93 & -0.0201 & $0.1519^{* * *}$ & -285.9 & $3,642.7^{* * *}$ & 0.986 & 0.985 \\
\hline Brazil & Nov-87 & Jul- $88 * * *$ & Mar-89 & 0.0013 & $0.0399 * * *$ & -16.6 & 71.6 & 0.924 & 0.914 \\
\hline Chile & Jan-86 & Feb-88 & Mar-90 & 0.0003 & $0.0230^{* * *}$ & -269.7 & $-906.3^{* * *}$ & -0.789 & -0.741 \\
\hline Colombia & Aug-93 & Sep- $93 * * *$ & Oct-93 & -0.0103 & $0.0206^{* * *}$ & -174.9 & $187.3 * * *$ & 0.826 & 0.939 \\
\hline Greece & May-85 & Jan- $87^{* * *}$ & Sep-88 & -0.0177 & $-0.0065^{* * *}$ & -44.3 & $-84.2^{* * *}$ & 0.155 & 0.645 \\
\hline India & Mar-93 & May-93*** & Jul-93 & 0.0006 & $0.0059 * * *$ & -251.0 & $-183.2 * * *$ & 0.163 & 0.846 \\
\hline Indonesia & Feb-93 & Jul-93 & Dec-93 & 0.0124 & $0.0603^{* * *}$ & 42.6 & $861.6^{* * *}$ & 0.977 & 0.967 \\
\hline Korea & Sep-91 & Apr-93* & Nov-94 & 0.0080 & $0.0321 * * *$ & -469.0 & $3,159.5^{* * *}$ & 0.921 & 0.908 \\
\hline Malaysia & Feb-9l & May-92 & Aug-93 & 0.0082 & $0.0162^{* * *}$ & -300.8 & $284.2 * * *$ & 0.514 & 0.581 \\
\hline Mexico & Jul-89 & Jun-90** & May-91 & 0.0753 & $0.1526^{* * *}$ & 213.7 & $10,765.4^{* * *}$ & 0.978 & 0.962 \\
\hline Pakistan & Apr-93 & May-93*** & Jun-93 & 0.0001 & $0.0090^{* * *}$ & 1.6 & $67.8^{* * *}$ & 0.950 & 0.929 \\
\hline Philippines & Feb-90 & Feb- $90^{* * *}$ & Feb-90 & 0.3240 & $0.1513^{* * *}$ & -195.8 & $-717.8^{* * *}$ & -0.475 & 0.226 \\
\hline Portugal & Jun-93 & Sep-94 & Dec-95 & 0.0231 & $0.0497^{* * *}$ & -161.3 & $-197.8^{* * *}$ & -0.826 & -0.468 \\
\hline Taiwan & Sep-88 & Sep-92 & & $0.000 \mathrm{l}$ & $0.0008^{* * *}$ & $-1,287.4$ & $-7,209.2^{* * *}$ & -0.394 & -0.432 \\
\hline Thailand & Feb-88 & Aug-88*** & Feb-89 & 0.0076 & $0.0322 * * *$ & -6.1 & $-145.5^{* * *}$ & 0.080 & 0.634 \\
\hline Turkey & May-88 & Jan-90 & Sep-9l & -0.0300 & $0.0067 * * *$ & -10.4 & $125.4 * * *$ & 0.803 & 0.616 \\
\hline Venezuela & Dec-93 & Mar-94*** & Jun-94 & -0.0072 & $0.0082^{* * *}$ & $1,044.1$ & $1,668.8^{* * *}$ & 0.505 & 0.230 \\
\hline $\begin{array}{l}\text { Mean } \\
P \text {-value } \\
(\text { continued) }\end{array}$ & & & & 0.0032 & $\begin{array}{l}0.0377 \\
0.01\end{array}$ & -123.5 & $\begin{array}{r}756.7 \\
0.17\end{array}$ & 0.423 & $\begin{array}{l}0.532 \\
0.31\end{array}$ \\
\hline
\end{tabular}




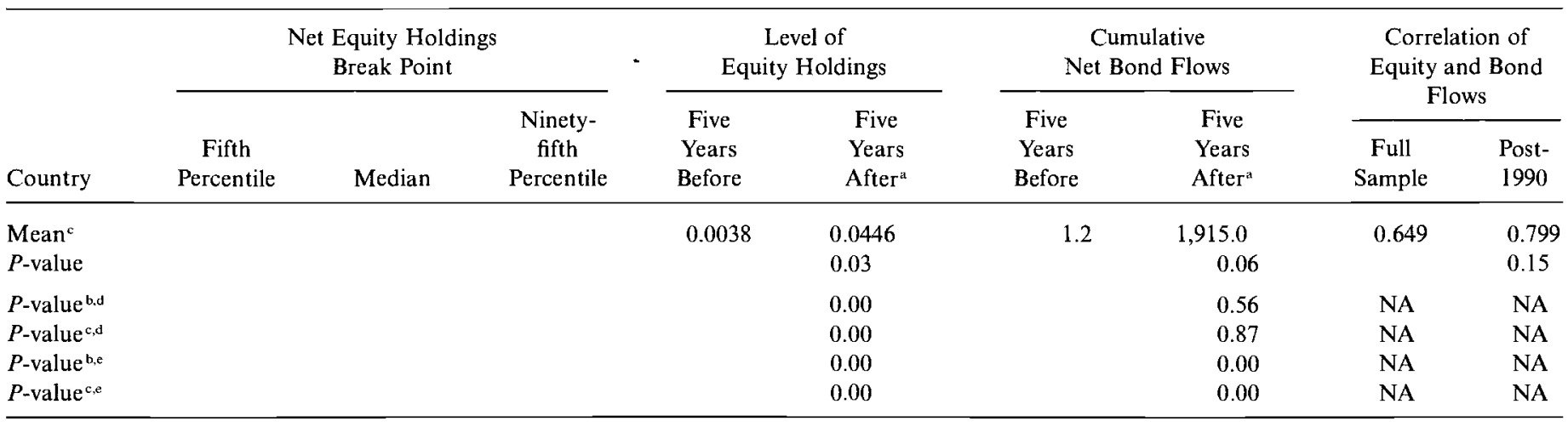

Note: Bond flows are reported in millions of U.S. dollars. All multivariate regression tests are corrected for group-wise heteroskedasticity and group-wise moving average processes in the residuals. NA $=$ not available.

"Probability values based on Newey-West corrected $t$-statistics from the regression

Series $=\mathbf{B} 0+($ Indicator for Five Years after Break $) * \mathbf{B} 1$.

${ }^{b}$ Excludes the Philippines which has a break down in capital flows

${ }^{c}$ Excludes the Philippines and countries with breaks that are not significant.

${ }^{\mathrm{d}} t$-statistic significance on a panel estimation with fixed effects of the regression

Series $[i, t]=\mathbf{B} 0[i]+($ Indicator for Five Years after Break $)[i, t] * \mathbf{B} 1$.

${ }^{e} \chi^{2}$ joint test that all of the coefficients are zero in the pooled time series regression with fixed effects

Series $[i, t]=\mathbf{B} 0[i]+($ Country Specific Indicator for Five Years after Break $)[i, t] * \mathbf{B} 1[i]$.

* Significant at the 10 percent level.

** Significant at the 5 percent level.

$* * *$ Significant at the 1 percent level 
frequency, we correct for a twelfth-order moving average process. The test statistics' $p$-values are denoted with asterisks.

The third set of tests involves a multivariate estimation with a single indicator variable that is activated after the break dates. The coefficient on this variable represents the average difference in the postbreak period. We test whether this single coefficient is different from zero. This estimation is groupwise heteroskedasticity consistent (allows for different variances across the countries). We also allow the errors to follow panel-specific moving average processes. Finally, we allow for fixed effects in the estimation.

The final test is another version of the multivariate test. In this test, we add country-specific indicator variables that pick up the country-specific difference between the prebreak and postbreak means. We conduct a groupwise heteroskedasticity- and moving-average-consistent Wald test that these coefficients equal zero.

Not surprisingly, equity flows increase significantly in all countries but the Philippines and U.S. ownership on average increases from less than 0.5 percent to $4-5$ percent of local market capitalization. The changes are significant in every country. Except for Brazil, the change in cumulative bond flows is statistically significant. The $\chi^{2}$ tests reveal a significant increase in cumulative bond flows that appears to be economically substantial.

Figure 6.1 allows a comparison of the patterns in equity and bond capital flows. In many countries, for example Argentina, there is a striking correlation between the equity and bond capital flows. In some countries (Brazil, Colombia, India, Indonesia, Malaysia, Thailand, and Turkey), the equity capital flows "lead" changes in the bond capital flows. In some other countries (Korea, Mexico, Pakistan, and Venezuela), the bond market distinctively changes before the equity market.

The final columns of table 6.1 report the correlations between the equity and bond flows. For the purpose of this table, we calculate the cumulative net equity flows, unadjusted for local market returns. This puts the equity flows on the same footing as the bond flows (which also do not include local market returns). The correlation is very high. There are six countries (Argentina, Brazil, Indonesia, Korea, Mexico, and Pakistan) with correlations above 90 percent. The correlations are even higher if we focus on the post-1990 period. In this sample, the average correlation between the equity and bond flows is 51 percent. In general, the evidence points to the bond and equity markets being complementary sources of foreign funding rather than substitutes. ${ }^{7}$

7. Negative correlations are found for Chile, Portugal, and Taiwan, which would suggest that the equity and bond markets might be substitutes in these countries. 


\subsection{Finance, Economics, and Changes in Capital Flows}

There are significant challenges in measuring equity volatility, correlation, and the cost of capital for emerging markets. We choose to follow the path of Bekaert and Harvey (1997) for volatility and correlation and Bekaert and Harvey (2000) for the cost of capital.

\subsubsection{The Cost of Capital}

Bekaert and Harvey (2000) argue that a change in the marginal investor and the different equity valuation it entails should have discrete effects on the price level of stocks (see also Korajczyk 1996). They argue that a technique exploiting information in price levels, as reflected in dividend yields, may be more powerful than trying to directly model expected returns. Indeed, the dividend yield has the advantage of being directly measurablethat is, it need not be pre-estimated - and being a stationary random variable. Moreover, shocks to prices should dominate its variation over time. Finally, the dividend yield is intricately linked to the cost of capital.

Consider a simple example from Bekaert and Harvey (2000). Assume rational expectations and a discounted dividend model for the stock price, $P_{i}$ :

$$
P_{t}=E_{t}\left[\sum_{i=1}^{\infty} \delta_{t+i}^{i} D_{t+i}\right]
$$

where $D_{t}$ are the dividends and $\delta_{t}$ is the discount factor. Let

$$
L_{t}= \begin{cases}0, & \text { before liberalization; } \\ 1, & \text { after liberalization. }\end{cases}
$$

Further assume that the liberalization is a one-time, unexpected event. When the market is segmented, the required rate of return is constant and equal to $r$. When the market opens up, the required rate of return drops to $\bar{r}$. We can represent this simple model for expected returns as

$$
\delta_{t}=\frac{1}{1+\frac{1}{\eta-}} \overline{\eta L_{t}},
$$

where $\eta=r-\bar{r}$, the drop in the cost of capital. Under this set of assumptions, the relation between the change in the dividend yield $\bar{D}_{t} / \bar{P}_{t}-D_{t} / P_{t}$ and the change in the cost of capital $\eta$ depends on the dividend process.

In the standard Gordon model, which assumes $E_{t} D_{t+i}=(1+g) E_{t} D_{t-1+i}$, this relation is virtually one to one..$^{8}$ It is straightforward to show:

8. The Gordon model is not a realistic model for stock price determination, but Bekaert and Harvey (2000) show that its main intuition remains valid with more general models. 


$$
\begin{aligned}
\eta & =r-\bar{r} \\
& =(1+g) \frac{D_{t}}{P_{t}}-(1+\bar{g}) \frac{\overline{D_{t}}}{P_{t}}+g-\bar{g} .
\end{aligned}
$$

If the growth rate of dividends is not affected by the capital market liberalization, a regression of $D_{t} / P_{t}$ onto the liberalization indicator variable, $L_{t}$, yields $-\eta /(1+g)$. Hence, the slope coefficient provides a slight underestimation of the true response of the cost of capital.

Bekaert and Harvey (2000) detail the potential problems in using this measure in cost of capital estimation. Nevertheless, it is a reasonable starting point. Table 6.2 shows that the dividend yield decreases in ten of sixteen countries after the capital flow break point (with capital flow increases). On average, the dividend yield decreases from 3.86 percent to 2.65 percent, implying a statistically significant (at the 10 percent level) reduction in the cost of capital. This analysis includes all countries except the Philippines, where a significant down break in capital flows occurred. If we specialize the analysis to the set of countries that experienced a significant increase in equity capital flows, the dividend yield moves from 4.27 percent to 2.47 percent. This decrease is also statistically significant across all of our tests.

Although much noisier, it is also possible to gain some insights from the log ex post returns. We find that the average U.S.-dollar returns in the five-year period before the capital equity flow break is 20.00 percent and 13.36 percent following the break. While this is a large absolute difference in average returns, the multivariate test is only significant at the 10 percent level. This is consistent with the simulations in Bekaert and Harvey (2000) that show it is much more difficult to observe a shift in the cost of capital by examining the behavior of equity returns.

\subsubsection{Volatility and Correlation}

We follow the work of Bekaert and Harvey (1997) and estimate a sophisticated time-series model for volatility for each country that allows both the conditional mean and the conditional variance to vary through time. ${ }^{9}$ We condition on both world and local information to capture the changes in the degree of market integration. This model delivers a time series of conditional volatilities for each country as well as conditional correlations of each country's return with the world market return.

Define the arithmetic excess return on the national equity index of country $i$ in U.S. dollars as $r_{i, l}$. Our model has three components. First, the conditional mean, $\mu_{i, t-1}$, is assumed to be time varying:

9. For other related work on volatility, see De Santis and İmrohoroğlu (1996), Aggarwal, Inclan, and Leal (1999), Kim and Singal (2000), and Richards (1996). 
Behavior of Equity Returns

\begin{tabular}{|c|c|c|c|c|c|c|c|c|c|c|c|c|}
\hline \multirow{2}{*}{ Country } & \multicolumn{2}{|c|}{ Dividend Yield } & \multicolumn{2}{|c|}{$\begin{array}{l}\text { Fitted Correlation } \\
\text { with World }\end{array}$} & \multicolumn{2}{|c|}{$\begin{array}{l}\text { Fitted Volatility } \\
\text { (annual) }\end{array}$} & \multicolumn{2}{|c|}{$\begin{array}{l}\text { Ex Post Log Returns } \\
\text { (annual) }\end{array}$} & \multicolumn{2}{|c|}{$\begin{array}{l}\text { Ex Post Volatility } \\
\text { (annual) }\end{array}$} & \multicolumn{2}{|c|}{$\beta s$} \\
\hline & $\begin{array}{l}\text { Five } \\
\text { Years } \\
\text { Before }\end{array}$ & $\begin{array}{c}\text { Five } \\
\text { Years } \\
\text { After }^{\text {a }}\end{array}$ & $\begin{array}{c}\text { Five } \\
\text { Years } \\
\text { Before }\end{array}$ & $\begin{array}{l}\text { Five } \\
\text { Years } \\
\text { After }\end{array}$ & $\begin{array}{c}\text { Five } \\
\text { Years } \\
\text { Before }\end{array}$ & $\begin{array}{l}\text { Five } \\
\text { Years } \\
\text { After }^{\text {a }}\end{array}$ & $\begin{array}{c}\text { Five } \\
\text { Years } \\
\text { Before }\end{array}$ & $\begin{array}{l}\text { Five } \\
\text { Years } \\
\text { After }^{\mathrm{a}}\end{array}$ & $\begin{array}{c}\text { Five } \\
\text { Years } \\
\text { Before }\end{array}$ & $\begin{array}{l}\text { Five } \\
\text { Years } \\
\text { After }\end{array}$ & $\begin{array}{c}\text { Five } \\
\text { Years } \\
\text { Before }\end{array}$ & $\begin{array}{l}\text { Five } \\
\text { Years } \\
\text { After }\end{array}$ \\
\hline Argentina & 1.99 & $2.94 * * *$ & 0.12 & $0.26 * * *$ & 119.67 & $60.34 * * *$ & 46.74 & 18.02 & 99.31 & 33.67 & -0.93 & 1.31 \\
\hline Brazil & 5.00 & 3.81 & 0.06 & 0.06 & 61.69 & $79.24 * * *$ & 23.48 & 13.35 & 61.94 & 79.21 & 0.26 & 1.22 \\
\hline Chile & 5.22 & $6.38^{* *}$ & 0.12 & $0.09 * * *$ & 33.55 & $31.86^{* *}$ & 19.00 & 39.23 & 34.60 & 24.72 & 0.58 & -0.09 \\
\hline Colombia & 5.04 & $1.89 * * *$ & 0.04 & $-0.02 * * *$ & 27.37 & 25.45 & 35.06 & 14.77 & 33.22 & 27.44 & 0.16 & 0.03 \\
\hline Greece & 9.91 & $4.24 * * *$ & 0.12 & $0.16^{* * *}$ & 26.46 & $46.86^{* * *}$ & -10.80 & 30.46 & 25.36 & 50.56 & -0.11 & 0.62 \\
\hline India & 1.67 & $1.09 * * *$ & -0.02 & $-0.18 * * *$ & 33.57 & 27.77 & 14.37 & 5.60 & 38.22 & 28.36 & -0.47 & 0.25 \\
\hline Indonesia & 0.84 & $1.40^{* *}$ & 0.06 & $0.32 * * *$ & 73.17 & 56.43 & -7.80 & 19.20 & 32.07 & 28.19 & 0.20 & 0.78 \\
\hline Korea & 1.33 & 1.33 & 0.22 & 0.21 & 27.78 & $25.95^{* *}$ & 2.42 & 5.83 & 29.74 & 22.64 & 0.68 & 0.51 \\
\hline Malaysia & 2.14 & $1.68 * * *$ & 0.48 & 0.49 & 21.42 & 22.87 & 10.74 & 17.82 & 28.22 & 24.87 & 1.10 & 0.72 \\
\hline Mexico & 3.62 & $1.82 * * *$ & 0.15 & $0.32 * * *$ & 46.38 & $35.79^{*}$ & 43.69 & 12.17 & 63.32 & 40.19 & 1.15 & 0.78 \\
\hline Pakistan & 5.23 & $1.80^{* * *}$ & 0.02 & $0.12^{* * *}$ & 32.29 & 30.87 & 17.70 & 5.59 & 26.34 & 26.34 & 0.03 & -0.11 \\
\hline Philippines & 2.75 & $1.05 * * *$ & 0.29 & $0.39 * * *$ & 35.69 & 34.90 & 63.32 & $11.04 * *$ & 35.56 & 34.64 & 0.57 & 0.87 \\
\hline Portugal & 3.09 & 3.20 & 0.51 & 0.50 & 26.67 & 19.30 & 3.35 & 13.23 & 24.52 & 14.26 & 0.90 & 0.48 \\
\hline Taiwan & 0.56 & $1.08 * * *$ & -0.04 & $0.21^{* * *}$ & 73.12 & 69.68 & 12.16 & 11.95 & 62.32 & 36.18 & 0.91 & 0.94 \\
\hline Thailand & 7.52 & $3.21 * * *$ & -0.10 & $0.38 * * *$ & 28.07 & 27.76 & 27.14 & 19.16 & 28.45 & 28.11 & 0.71 & 0.55 \\
\hline Turkey & 7.13 & $4.00^{* * *}$ & -0.39 & $0.02 * * *$ & 96.80 & $68.40^{*}$ & 59.38 & -5.31 & 74.41 & 64.37 & 0.47 & 0.09 \\
\hline Venezuela & 1.41 & $2.55^{* * *}$ & 0.08 & $0.00^{* * *}$ & 52.77 & 58.07 & 23.36 & -7.30 & 48.37 & 61.11 & -0.39 & -0.35 \\
\hline
\end{tabular}




\begin{tabular}{|c|c|c|c|c|c|c|c|c|c|c|c|c|}
\hline $\begin{array}{l}\text { Mean }{ }^{b} \\
P \text {-value }\end{array}$ & 3.86 & $\begin{array}{l}2.65 \\
0.07\end{array}$ & 0.09 & $\begin{array}{l}0.18 \\
0.10\end{array}$ & 48.80 & $\begin{array}{r}42.91 \\
0.21\end{array}$ & 20.00 & $\begin{array}{r}13.36 \\
0.13\end{array}$ & 44.40 & $\begin{array}{r}36.89 \\
0.15\end{array}$ & 0.33 & $\begin{array}{l}0.48 \\
0.11\end{array}$ \\
\hline Mean $^{c}$ & 4.27 & 2.47 & 0.07 & 0.13 & 44.81 & 40,00 & 22.32 & 11.76 & 45.43 & 39.76 & 0.11 & 0.48 \\
\hline$P$-value & & 0.00 & & 0.25 & & 0.12 & & 0.02 & & 0.24 & & 0.04 \\
\hline$P$-value ${ }^{\mathrm{b}, \mathrm{d}}$ & & 0.08 & & 0.19 & & 0.09 & & 0.73 & & NA & & NA \\
\hline$P$-value ${ }^{\mathrm{c} . \mathrm{d}}$ & & 0.11 & & 0.37 & & 0.08 & & 0.61 & & $\mathrm{NA}$ & & NA \\
\hline$P$-value ${ }^{\text {b.e }}$ & & 0.00 & & 0.00 & & 0.27 & & 0.97 & & $\mathrm{NA}$ & & NA \\
\hline$P$-value ${ }^{\mathrm{c}, \mathrm{e}}$ & & 0.07 & & 0.00 & & 0.25 & & 0.94 & & NA & & NA \\
\hline
\end{tabular}

Note: All multivariate regression tests are corrected for group-wise heteroskedasticity and group-wise moving average processes in the residuals. NA $=$ not available.

${ }^{a}$ Probability values based on Newey-West corrected $t$-statistics from the regression

$$
\text { Series }=\mathbf{B} 0+(\text { Indicator for Five Years after Break }) * \mathbf{B} 1 .
$$

${ }^{b}$ Excludes the Philippines which has a break down in capital flows.

${ }^{\circ}$ Excludes the Philippines and countries with breaks that are not significant.

${ }^{\mathrm{d}} t$-statistic significance on a panel estimation with fixed effects of the regression

$$
\text { Series }[i, t]=\mathrm{B} 0[i]+(\text { Indicator for Five Years after Break })[i, t] * \mathbf{B} 1 \text {. }
$$

${ }^{e} \chi^{2}$ joint test that all of the coefficients are zero in the pooled time series regression with fixed effects

$$
\text { Series }[i, t]=\mathrm{B} 0[i]+(\text { Country Specific Indicator for Five Years after Break })[i, t] * \mathrm{~B} 1[i] .
$$

*Significant at the 10 percent level.

** Significant at the 5 percent level.

*** Significant at the 1 percent level. 


$$
r_{i, t}=\mu_{i, t-1}+\varepsilon_{i, t}
$$

Second, the unexpected return, $\varepsilon_{i, t}$ is determined by both a common world shock, $\varepsilon_{\mathrm{u}, t}$ and a purely idiosyncratic (country-specific) shock, $e_{i, t}$,

$$
\varepsilon_{i, t}=v_{i, t-1} \varepsilon_{w, t}+e_{i, t},
$$

where $v_{i, t-1}$ is a time-varying weight that reveals the relative importance of world versus local information. Finally, the local idiosyncratic conditional variance, $\left(\sigma_{i, t}^{\ell}\right)^{2}$, follows an asymmetric GARCH $(1,1)$ model which follows from the work of Glosten, Jagannathan, and Runkle (1993):

$$
\left(\sigma_{i, t}^{\ell}\right)^{2}=E\left[e_{i, t}^{2} \mid I_{t-1}\right]=c_{i}+\alpha_{i}\left(\sigma_{i, t-1}^{\ell}\right)^{2}+\beta_{i} e_{i, t-1}^{2}+\gamma_{i} S_{i, t} e_{i, t-1}^{2},
$$

where $I_{t-1}$ is the information available at time $t-1$ and $S_{i, t}$ is an indicator variable that takes on the value of 1 when the idiosyncratic shock is negative and 0 otherwise. We also assume that

$$
e_{i, t}=\sigma_{i, t}^{\ell} z_{i, t},
$$

where $z_{l, t}$ is a standardized residual with zero mean and unit variance. We investigate two distributional assumptions for the standardized residual, $z_{i, f}:$ the normal distribution and a mixture of normal distributions. The latter distribution allows for both skewness and kurtosis.

The conditional mean of country i's return is assumed to be linear in a set of global and local information variables. The global information variables include a constant, the world market dividend yield in excess of the thirty-day Eurodollar rate, the default spread (Moody's Baa minus Aaa bond yields), the change in the term structure spread (U.S. ten-year bond yield minus three-month U.S. bill), and the change in the thirty-day Eurodollar rate. These variables are designed to capture fluctuations in expectations of the world business cycle (see Harvey 1991). The local information variables include a constant, the equity return, the exchange rate change, the dividend yield, equity market capitalization to (GDP), and trade to GDP. All of the information variables are known at time $t-1$. The financial variables are lagged by one month and the macroeconomic variables are lagged by one year to allow for reporting delays.

The world market expected returns and variances are a special case of equations (1)-(5), with $i=w, \sigma_{i, t}^{\ell}=\sigma_{w, t}, v_{w, t-1}=0$. The conditional mean of the world market return, $\mu_{w, t-1}$, is assumed to be a linear function of global information variables. Finally, the relative importance of world versus local information in the variance equation is defined as

$$
v_{i, t-1}=\mathbf{q}_{i, 0}+\mathbf{q}_{i, 1}^{\prime} \mathbf{X}_{i, t-1}^{* \prime},
$$


where, following Bekaert and Harvey (1997), $\mathbf{X}_{i, t-1}^{*}$ includes the subset of the local information variables that might proxy for the degree of market integration: market capitalization to GDP and the size of the trade sector (exports plus imports divided by GDP). The data for this exercise are U.S.dollar total return indices for twenty countries provided by the IFC and the sample covers 1976-95. These data are described in more detail in Bekaert and Harvey (1995).

The results are contained in table 6.2. In eleven of seventeen countries, the fitted correlation with the world increases. On average the correlation increases from 0.09 to 0.18 , which is significant in the multivariate tests that allow for country-specific coefficients. We also calculated ex post $\beta \mathrm{s}$ with the Morgan Stanley Capital International world market portfolio. The $\beta$ s increase from an average of 0.33 to 0.48 , which is significant at the 11 percent level. When we examine only the countries with significant increases in equity flows, the $\beta$ s increase from an average of 0.11 to 0.48 . This change is significant at the 5 percent level and suggestive of higher correlations with world aggregates. ${ }^{10}$

The results for volatility are more ambiguous. The fitted volatility declines in nine of seventeen countries. On average, volatility falls from 49 percent (on an annual basis) to 43 percent after the break in net capital flows, but the difference is not significant. On the other hand, when we look at the ex post volatility of the returns, there is more of a change. In the early period, the volatility is 44 percent, which falls to 37 percent in the later period. This decrease in volatility is not significant. These results suggest that volatility neither systematically increases nor decreases after capital flow breaks.

\subsubsection{Financial Market Indicators}

Table 6.3 details the behavior of a number of financial market indicators. We find that on average the number of stocks included in the IFC index significantly increases from thirty-five to fifty-seven after the break in capital flows. The IFC index attempts to cover 70 percent of market capitalization (see Bekaert and Harvey 1995). It seems like more stocks are being included in the country indices to attain the 70 percent minimum.

This suggests a pattern in stock market growth in the emerging markets. It is not as simple as the largest firms getting larger. Additional firms are entering the equity market and smaller current firms are becoming larger. This is consistent with the data on concentration ratios. The concentration ratio (modified Herfindahl ratio) declines, albeit insignificantly, after the

10. The pooled regression tests are not available for the $\beta s$ or the ex post volatility because only two observations are available for each country, prebreak $\beta$ (volatility) and postbreak $\beta$ (volatility). 
Financial Indicators

\begin{tabular}{|c|c|c|c|c|c|c|c|c|c|c|c|c|c|c|}
\hline \multirow[b]{2}{*}{ Country } & \multicolumn{2}{|c|}{$\begin{array}{l}\text { Number of } \\
\text { Companies }\end{array}$} & \multicolumn{2}{|c|}{$\begin{array}{c}\text { Concentration } \\
\text { Ratio }\end{array}$} & \multicolumn{2}{|c|}{$\begin{array}{c}\text { Market } \\
\text { Capitalization } \\
\text { to GDP }\end{array}$} & \multicolumn{2}{|c|}{$\begin{array}{c}\text { Cross-Sectional } \\
\text { Standard Deviation }\end{array}$} & \multicolumn{2}{|c|}{$\begin{array}{c}\text { Exchange Rate } \\
\text { Volatility }\end{array}$} & \multicolumn{2}{|c|}{$\begin{array}{l}\text { Value Traded } \\
\text { to GDP }\end{array}$} & \multicolumn{2}{|c|}{ Turnover } \\
\hline & $\begin{array}{l}\text { Five } \\
\text { Years } \\
\text { Before }\end{array}$ & $\begin{array}{l}\text { Five } \\
\text { Years } \\
\text { After" }\end{array}$ & $\begin{array}{l}\text { Five } \\
\text { Years } \\
\text { Before }\end{array}$ & $\begin{array}{l}\text { Five } \\
\text { Years } \\
\text { After" }\end{array}$ & $\begin{array}{l}\text { Five } \\
\text { Years } \\
\text { Before }\end{array}$ & $\begin{array}{l}\text { Five } \\
\text { Years } \\
\text { After }\end{array}$ & $\begin{array}{l}\text { Five } \\
\text { Years } \\
\text { Before }\end{array}$ & $\begin{array}{l}\text { Five } \\
\text { Years } \\
\text { After }\end{array}$ & $\begin{array}{l}\text { Five } \\
\text { Years } \\
\text { Before }\end{array}$ & $\begin{array}{l}\text { Five } \\
\text { Years } \\
\text { After" }\end{array}$ & $\begin{array}{l}\text { Five } \\
\text { Years } \\
\text { Before }\end{array}$ & $\begin{array}{l}\text { Five } \\
\text { Years } \\
\text { After }^{2}\end{array}$ & $\begin{array}{l}\text { Five } \\
\text { Years } \\
\text { Before }\end{array}$ & $\begin{array}{l}\text { Five } \\
\text { Years } \\
\text { After" }\end{array}$ \\
\hline Argentina & 25.78 & $32.10^{* * *}$ & 0.28 & 0.29 & 0.04 & $0.08^{* * *}$ & 0.25 & $0.12^{* * *}$ & 0.38 & $0.03^{* * *}$ & 2.09 & 2.55 & 0.47 & $0.30^{* * *}$ \\
\hline Brazil & 21.42 & $56.93^{* * *}$ & 0.29 & $0.18^{* * *}$ & 0.04 & $0.05^{* * *}$ & 0.21 & $0.26^{* *}$ & 0.06 & $0.14^{* * *}$ & 1.47 & $2.04^{* *}$ & 0.42 & 0.38 \\
\hline Chile & 23.90 & $29.62^{* * *}$ & 0.22 & 0.22 & 0.09 & $0.46^{* * *}$ & 0.14 & $0.10^{* * *}$ & 0.05 & $0.02^{* * *}$ & 0.86 & $2.67^{* * * *}$ & 0.08 & 0.09 \\
\hline Colombia & 20.25 & $24.42^{* * *}$ & 0.19 & $0.20^{* *}$ & 0.07 & $0.19^{* * *}$ & 0.13 & 0.12 & 0.02 & $0.02^{* * *}$ & 0.36 & $1.40^{* * *}$ & 0.06 & $0.10^{* * *}$ \\
\hline Greece & 10.00 & $21.57^{* * *}$ & 0.57 & $0.27^{* * *}$ & 0.02 & $0.09^{* * *}$ & 0.09 & $0.13^{* * * *}$ & 0.04 & $0.03^{*}$ & 0.04 & $1.46^{* * * *}$ & 0.04 & $0.14^{* * *}$ \\
\hline India & 58.63 & $118.78^{* * *}$ & 0.18 & $0.12^{* * *}$ & 0.07 & $0.21^{* * * *}$ & 0.12 & $0.10^{*}$ & 0.02 & 0.02 & 3.53 & $2.91^{* *}$ & 0.75 & $0.18^{* * *}$ \\
\hline Indonesia & 62.51 & $45.71^{* * *}$ & 0.19 & 0.20 & 0.08 & $0.13^{* * *}$ & 0.12 & 0.11 & 0.01 & $0.00^{* * *}$ & 1.80 & $4.11^{* * *}$ & 0.44 & 0.36 \\
\hline Korea & 70.07 & $152.27 * * *$ & 0.18 & $0.21^{* * * *}$ & 0.27 & $0.31 * *$ & 0.07 & $0.09^{* *}$ & 0.01 & $0.01^{* * *}$ & 18.80 & $31.40^{* * *}$ & 0.84 & $1.08^{* *}$ \\
\hline Malaysia & 55.32 & $90.17^{* * *}$ & 0.19 & 0.19 & 0.64 & $1.70^{* * *}$ & 0.09 & 0.09 & 0.01 & $0.01^{* * *}$ & 7.77 & $51.72^{* * *}$ & 0.13 & $0.33^{* * *}$ \\
\hline Mexico & 34.13 & $66.56^{* * * *}$ & 0.16 & $0.26^{* * *}$ & 0.07 & $0.23^{* * *}$ & 0.19 & $0.11^{* * *}$ & 0.07 & $0.02^{* * *}$ & 2.41 & $9.85^{* * *}$ & 0.71 & $0.46^{* * *}$ \\
\hline Pakistan & 52.50 & $71.00^{* * *}$ & 0.16 & $0.15^{*}$ & 0.05 & $0.15^{* * *}$ & 0.09 & $0.11^{* *}$ & 0.01 & $0.02^{* * *}$ & 0.42 & $3.25^{* * *}$ & 0.08 & $0.36^{* * *}$ \\
\hline Philippines & 18.00 & $32.82^{* * *}$ & 0.31 & $0.29^{*}$ & 0.05 & $0.25^{* * *}$ & 0.14 & 0.13 & 0.02 & 0.02 & 1.56 & $4.73^{* * *}$ & 0.30 & $0.19^{* * *}$ \\
\hline Portugal & 30.02 & $31.38^{*}$ & 0.22 & $0.20^{* * *}$ & 0.11 & $0.14^{* * *}$ & 0.09 & $0.07^{* *}$ & 0.04 & 0.04 & 1.82 & $3.20^{* * *}$ & 0.20 & $0.31^{* * *}$ \\
\hline Taiwan & 57.58 & $84.13^{* * *}$ & 0.19 & $0.16^{* * *}$ & 0.62 & $0.50^{*}$ & 0.11 & $0.08^{* * *}$ & 0.01 & $0.01^{* * *}$ & 172.44 & $100.03^{* * *}$ & 2.84 & $1.97^{* * *}$ \\
\hline Thailand & 9.72 & $37.90^{* * *}$ & 0.32 & $0.23^{* * *}$ & 0.04 & $0.21^{* * *}$ & 0.08 & $0.11^{* * *}$ & 0.02 & $0.01^{* * *}$ & 2.12 & $14.23^{* * *}$ & 0.49 & $0.71^{* *}$ \\
\hline Turkey & 15.14 & $27.95^{* * *}$ & 0.23 & 0.25 & 0.03 & $0.12^{* * *}$ & 0.17 & 0.18 & 0.02 & $0.03^{* *}$ & 0.23 & $3.90^{* * *}$ & 0.10 & $0.55^{* * *}$ \\
\hline Venezuela & 15.25 & $16.70^{* * *}$ & 0.25 & $0.34^{* * *}$ & 0.10 & $0.07^{* * *}$ & 0.16 & $0.12^{* *}$ & 0.04 & $0.09^{* * *}$ & 3.12 & $1.09^{* * *}$ & 0.33 & $0.18^{* * *}$ \\
\hline
\end{tabular}




\begin{tabular}{|c|c|c|c|c|c|c|c|c|c|c|c|c|c|c|}
\hline Mean $^{b}$ & 35.14 & 56.70 & 0.24 & 0.22 & 0.15 & 0.29 & 0.13 & 0.12 & 0.16 & 0.11 & 13.70 & 14.74 & 0.50 & 0.47 \\
\hline$P$-value & & 0.03 & & 0.22 & & 0.11 & & 0.24 & & 0.24 & & 0.47 & & 0.44 \\
\hline Mean $^{\circ}$ & 31.78 & 59.82 & 0.26 & 0.23 & 0.08 & 0.16 & 0.14 & 0.13 & 0.07 & 0.04 & 3.43 & 7.02 & 0.42 & 0.39 \\
\hline$P$-value & & 0.05 & & 0.24 & & 0.02 & & 0.33 & & 0.25 & & 0.16 & & 0.42 \\
\hline$P$-value ${ }^{b, d}$ & & 0.02 & & 0.20 & & 0.00 & & 0.20 & & 0.36 & & 0.00 & & 0.01 \\
\hline$P$-value ${ }^{\mathrm{c}, \mathrm{d}}$ & & 0.00 & & 0.06 & & 0.00 & & 0.86 & & 0.64 & & 0.07 & & 0.03 \\
\hline$P$-value b.c $^{\text {b.c }}$ & & 0.00 & & 0.00 & & 0.00 & & 0.00 & & 0.00 & & 0.00 & & 0.00 \\
\hline$P$-value c,c & & 0.00 & & 0.00 & & 0.03 & & 0.00 & & 0.00 & & 0.00 & & 0.00 \\
\hline
\end{tabular}

Note: All multivariate regression tests are correcied for group-wise heteroskedasticity and group-wise moving average processes in the residuals.

-Probability values based on Newey-West corrected $t$-statistics from the regression

Series $=\mathbf{B O}+($ Indicator for Five Years after Break $) * \mathbf{B} \mathbf{1}$.

'Excludes the Philippines which has a break down in capital flows.

'Excludes the Philippines and countries with breaks that are not significant.

${ }^{d} t$-statistic significance on a panel estimation with fixed effects of the regression

Series $[i, t]=\mathrm{B} 0[i]+($ Indicator for Five Years after Break $)[i, t] * \mathrm{~B} 1$.

' $\chi \chi^{2}$ joint test that all of the coefficients are zero in the pooled time series regression with fixed effects

Series $[i, t]=\mathrm{B} 0[i]+($ Country Specific Indicator for Five Years after Break $)[i, t] * \mathrm{~B} 1[i]$.

* Significant at the 10 percent level.

**Significant at the 5 percent level.

*** Significant at the 1 percent level. 
break in capital flows. This is consistent with some smaller firms increasing in size at a rate faster than the larger firms. The cross-sectional average may also be influenced by a number of countries (e.g., Mexico) where privatizations introduced a number of large firms to the market.

Market capitalization to GDP increases after the flows break point. Market capitalization to GDP increases in fourteen of sixteen countries. On average the equity market accounts for 15 percent of GDP before the break and 29 percent of GDP after the break. The multivariate tests suggest that this increase is significant, leaving little doubt that the size of the equity market relative to GDP increases.

We also examine the cross-sectional volatility of the individual security returns. This is a monthly measure of dispersion. If all of the securities were in one particular industry, the returns would be highly correlated and the cross-sectional volatility would be low. With industrial diversification, the cross-sectional volatility would be high. The results in table 6.3 show no particular pattern.

We examine two liquidity indicators: average value traded divided by GDP and turnover. Average value traded is the average monthly value of the shares traded in millions of U.S. dollars. We divide this by the previous year's GDP. This ratio sharply increases in a number of countries. The overall ratio's change is significant at the 10 percent level for those countries that had a significant break in capital flows. The turnover ratio is the total value of shares traded during the month divided by the average market capitalization. Some countries show significant increases in turnover and some show significant decreases. Overall, there are no particular patterns when examining the turnover ratio. Of course, some caution needs to be exercised in comparing the ratios across countries. Taiwan, for example, is an extremely influential observation. For interpretation, the emphasis should be placed on our multivariate tests that tend to downweight these influential observations in a generalized least squares framework.

Finally, we look at the foreign exchange (FX) market. We calculate a trailing annualized three-year standard deviation of exchange rate changes. The multivariate test that allows for country-specific coefficients suggest significant changes in FX volatility. The volatility of the FX rate is almost cut in half after the break in capital flows. The most dramatic decreases in FX volatility are found in Argentina and Mexico. Of course, dramatic changes in FX volatility could be induced by moving from a float to a pegged regime or by stabilization plans in countries with rampant inflation. A chronology of the currency regimes in the emerging markets can be found at www.duke.edu/ charvey/Country_risk/couindex.htm.

\subsubsection{The Economy}

Table 6.4 details the association of capital flow breaks and fundamental economic variables. There are a number of interesting features. First, in 


\begin{tabular}{|c|c|c|c|c|c|c|c|c|c|c|c|c|c|c|c|c|c|c|}
\hline \multirow[b]{2}{*}{ Country } & \multicolumn{2}{|c|}{$\begin{array}{l}\text { Real GDP per } \\
\text { Capita Growth }\end{array}$} & \multicolumn{2}{|c|}{$\begin{array}{l}\text { Average (exports } \\
\text { and imports)/ } \\
\text { GDP }(\%)\end{array}$} & \multicolumn{2}{|c|}{$\begin{array}{c}\text { Average Trade } \\
\text { Surplus/GDP } \\
(\%)\end{array}$} & \multicolumn{2}{|c|}{$\begin{array}{l}\text { Average Inflation } \\
-\quad(\text { annual } \%)\end{array}$} & \multicolumn{2}{|c|}{$\begin{array}{l}\text { Interest Rate } \\
\text { (lending)" }\end{array}$} & \multicolumn{2}{|c|}{$\begin{array}{c}\text { Real Exchange } \\
\text { Rate }\end{array}$} & \multicolumn{2}{|c|}{$\begin{array}{c}\text { External Debt } \\
(\% \text { GDP })\end{array}$} & \multicolumn{2}{|c|}{$\begin{array}{l}\text { Long-Term } \\
\text { External Debt } \\
\text { (\% GDP) }\end{array}$} & \multicolumn{2}{|c|}{$\begin{array}{l}\text { Government } \\
\text { Surplus } \\
\text { (\% GDP) }\end{array}$} \\
\hline & $\begin{array}{l}\text { Five } \\
\text { Years } \\
\text { Before }\end{array}$ & $\begin{array}{l}\text { Five } \\
\text { Years } \\
\text { After }\end{array}$ & $\begin{array}{l}\text { Five } \\
\text { Years } \\
\text { Before }\end{array}$ & $\begin{array}{l}\text { Five } \\
\text { Years } \\
\text { After }^{\mathrm{b}}\end{array}$ & $\begin{array}{l}\text { Five } \\
\text { Years } \\
\text { Before }\end{array}$ & $\begin{array}{l}\text { Five } \\
\text { Years } \\
\text { After" }\end{array}$ & $\begin{array}{l}\text { Five } \\
\text { Years } \\
\text { Before }\end{array}$ & $\begin{array}{l}\text { Five } \\
\text { Years } \\
\text { After }^{\mathrm{b}}\end{array}$ & $\begin{array}{l}\text { Five } \\
\text { Years } \\
\text { Before }\end{array}$ & $\begin{array}{l}\text { Five } \\
\text { Years } \\
\text { After" }\end{array}$ & $\begin{array}{l}\text { Five } \\
\text { Years } \\
\text { Before }\end{array}$ & $\begin{array}{l}\text { Five } \\
\text { Years } \\
\text { After }\end{array}$ & $\begin{array}{l}\text { Five } \\
\text { Years } \\
\text { Before }\end{array}$ & $\begin{array}{l}\text { Five } \\
\text { Years } \\
\text { After }{ }^{b}\end{array}$ & $\begin{array}{l}\text { Five } \\
\text { Years } \\
\text { Before }\end{array}$ & $\begin{array}{l}\text { Five } \\
\text { Years } \\
\text { After }\end{array}$ & $\begin{array}{l}\text { Five } \\
\text { Years } \\
\text { Before }\end{array}$ & $\begin{array}{l}\text { Five } \\
\text { Years } \\
\text { After }\end{array}$ \\
\hline Argentina & 0.757 & 1.314 & 19.45 & $26.56^{* * *}$ & 0.63 & $3.43^{* * *}$ & $1,410.35$ & $4.87^{* * *}$ & $3,822.78$ & $10.42^{* * *}$ & 95.08 & $50.72^{* * *}$ & 47.1 & $29.0^{* * *}$ & 37.4 & $24.2^{* * * *}$ & -0.78 & $0.00^{* * *}$ \\
\hline Brazil & 2.404 & $-1.741 * * *$ & 15.57 & $18.97^{* * *}$ & 3.29 & $-1.31^{* * *}$ & 220.88 & $1,475.31 * * *$ & 304.35 & $3,867.19 * * *$ & 187.06 & $125.11^{* * *}$ & 44.1 & $30.1^{* * *}$ & 37.9 & $24.4^{* * * *}$ & -10.01 & $-7.76^{*}$ \\
\hline Chile & 2.783 & $5.779^{* * *}$ & 55.94 & $67.42^{* * *}$ & 3.18 & $-0.54^{* * *}$ & 23.50 & $19.08^{* * *}$ & 36.20 & $31.70^{* *}$ & 94.66 & $100.12^{*}$ & 108.1 & $61.8^{* * *}$ & 92.0 & $49.1^{* * *}$ & -1.67 & $1.22 * * *$ \\
\hline Colombia & 1.795 & $3.510^{* * *}$ & 34.76 & $46.82^{* * *}$ & -2.56 & $4.37 * * *$ & 27.56 & $22.05^{* * *}$ & 42.26 & 40.56 & 96.97 & $72.10^{* * *}$ & 39.7 & $28.7 * * *$ & 35.1 & $21.9^{* * *}$ & 0.36 & $-0.55^{* *}$ \\
\hline Greece & 0.852 & 1.161 & 42.91 & $61.93^{* * *}$ & -6.94 & $0.29 * * *$ & 20.51 & $16.73^{* * *}$ & 20.51 & $24.80^{* * *}$ & 138.25 & $109.39 * * *$ & NA & $\mathrm{NA}^{\circ}$ & NA & $\mathrm{NA}^{*}$ & -12.65 & $-20.28 * * *$ \\
\hline India & 3.137 & 3.673 & 15.18 & $17.87^{* * *}$ & -0.49 & $0.59 * * *$ & 9.87 & 9.09 & 17.25 & $16.30^{* * *}$ & 99.08 & 97.30 & 30.5 & $32.9^{*}$ & 26.7 & $30.1 * * *$ & -7.09 & $-6.29^{* *}$ \\
\hline Indonesia & 6.103 & 5.788 & 42.89 & $47.27^{* * *}$ & -0.13 & -1.10 & 7.91 & $9.19^{* * *}$ & 21.90 & $18.34^{* * *}$ & 109.47 & $135.56^{* * *}$ & 60.8 & $55.1^{* * * *}$ & 50.3 & $44.4^{* * *}$ & -0.59 & $0.61^{* * *}$ \\
\hline Korea & 6.832 & 6.604 & 75.44 & $90.11^{* * *}$ & 3.90 & 4.55 & 7.32 & $5.17^{* * *}$ & 10.23 & $8.70^{* * *}$ & 100.76 & 100.84 & NA & $\mathrm{NA}^{\circ}$ & NA & $\mathrm{NA}^{\mathrm{E}}$ & -0.25 & $0.31^{* * * *}$ \\
\hline Malaysia & 5.540 & $6.046^{*}$ & 140.16 & $182.51^{* * *}$ & 5.82 & 6.21 & 2.71 & $4.26^{* * *}$ & 7.62 & $8.47^{* * *}$ & 106.47 & $94.55^{* * *}$ & 47.3 & $39.8^{* * *}$ & 42.0 & $31.0^{* * * *}$ & -1.41 & $1.87^{* * * *}$ \\
\hline Mexico & -1.041 & $0.281^{*}$ & 35.61 & $51.00^{* * *}$ & 3.28 & $9.16^{* * *}$ & 81.03 & $16.14^{* * *}$ & 66.39 & $19.28^{* * *}$ & 90.38 & $95.29^{* * *}$ & 61.6 & $39.3^{* * * *}$ & 54.5 & $28.3^{* * * *}$ & -10.25 & $\mathrm{NA}^{\mathrm{c}}$ \\
\hline Pakistan & 2.534 & $0.590^{* * *}$ & 31.77 & $34.08^{* * *}$ & -1.73 & $1.19^{* * *}$ & 9.59 & $11.45^{* * *}$ & NA & $\mathrm{NA}^{*}$ & 98.63 & $105.75^{* * *}$ & 48.9 & 50.0 & 39.0 & $43.1^{* * *}$ & -7.03 & -6.82 \\
\hline Philippines & 0.141 & -0.284 & 52.62 & $70.43^{* * *}$ & 1.15 & $4.37 * * *$ & 10.06 & 11.77 & 18.92 & 19.30 & 98.79 & $91.42^{* * *}$ & 83.0 & $66.3^{* * *}$ & 63.7 & $54.4^{* * * *}$ & -2.89 & $-2.06 * * *$ \\
\hline Portugal & 0.019 & 1.594 & 83.00 & $94.18^{* * *}$ & 10.75 & $15.41 * * *$ & 9.76 & $3.91^{* * *}$ & 20.12 & $14.33^{* * *}$ & 96.48 & $92.18^{*}$ & $\mathrm{NA}$ & $\mathrm{NA}^{\mathrm{c}}$ & NA & $\mathrm{NA}^{\mathrm{a}}$ & -4.21 & $\mathrm{NA}^{\mathrm{c}}$ \\
\hline Taiwan & 4.349 & 5.281 & 80.27 & $75.93^{* * * *}$ & 8.78 & $3.47 * * *$ & 3.28 & 3.55 & NA & $\mathrm{NA}^{*}$ & NA & $\mathrm{NA}^{\mathrm{*}}$ & NA & $\mathrm{NA}^{\mathrm{c}}$ & $\mathrm{NA}$ & $\mathrm{NA}^{*}$ & NA & $\mathrm{NA}^{\mathrm{c}}$ \\
\hline Thailand & 4.801 & $8.687^{* * *}$ & 53.18 & $77.91 * * *$ & -2.06 & $2.93^{* * *}$ & 2.38 & $4.90^{* * *}$ & 17.22 & 16.63 & 98.57 & 98.98 & 39.8 & $35.2^{* * *}$ & 30.2 & $24.4^{* * *}$ & -3.35 & $3.24^{* * *}$ \\
\hline Turkey & 2.436 & 1.726 & 32.61 & $40.74^{* * *}$ & -0.95 & $3.79 * * *$ & 50.85 & $72.10^{* * *}$ & 45.47 & $65.55^{* * *}$ & 131.52 & $105.68^{* * * *}$ & 42.4 & $38.0^{* * * *}$ & 34.1 & $30.2^{* * *}$ & -3.63 & $-4.61^{* * *}$ \\
\hline Venezuela & 0.319 & $-2.588^{* *}$ & 47.00 & $49.56^{* * *}$ & -1.82 & $-8.32^{* * *}$ & 46.33 & $65.35^{* * *}$ & 33.08 & $39.30^{* *}$ & 93.85 & $79.31^{* * *}$ & 66.1 & $55.5^{* * *}$ & 55.3 & $46.5^{* * *}$ & -0.33 & $-4.14^{* * *}$ \\
\hline Mean ${ }^{3}$ & 2.73 & 2.98 & 50.36 & 61.43 & 1.43 & 2.76 & 21.61 & 18.78 & 28.19 & 25.33 & 104.24 & 99.00 & 53.04 & 41.28 & 44.54 & 33.12 & -4.19 & -3.32 \\
\hline$P$-value & & 0.40 & & 0.20 & & 0.22 & & 0.37 & & 0.17 & & 0.16 & & 0.03 & & 0.34 & & 0.00 \\
\hline Mean" & 2.24 & 2.15 & 37.09 & 47.48 & -0.45 & 1.69 & 25.57 & 18.86 & 29.56 & 23.65 & 102.06 & 94.87 & 47.23 & 37.59 & 39.52 & 30.35 & -5.14 & -4.70 \\
\hline$P$-value & & 0.47 & & 0.15 & & 0.12 & & 0.29 & & 0.03 & & 0.02 & & 0.04 & & 0.44 & & 0.00 \\
\hline
\end{tabular}

(continued) 


\begin{tabular}{|c|c|c|c|c|c|c|c|c|c|c|c|c|c|c|c|c|c|c|}
\hline \multirow[b]{2}{*}{ Country } & \multicolumn{2}{|c|}{$\begin{array}{l}\text { Real GDP per } \\
\text { Capita Growth }\end{array}$} & \multicolumn{2}{|c|}{$\begin{array}{l}\text { Average (exports } \\
\text { and imports)/ } \\
\text { GDP (\%) }\end{array}$} & \multicolumn{2}{|c|}{$\begin{array}{c}\text { Average Trade } \\
\text { Surplus/GDP } \\
(\%)\end{array}$} & \multicolumn{2}{|c|}{$\begin{array}{l}\text { Average Inflation } \\
\text { (anmual \%) }\end{array}$} & \multicolumn{2}{|c|}{$\begin{array}{l}\text { Interest Rate } \\
\text { (lending) }\end{array}$} & \multicolumn{2}{|c|}{$\begin{array}{l}\text { Real Exchange } \\
\text { Rate }\end{array}$} & \multicolumn{2}{|c|}{$\begin{array}{c}\text { External Debt } \\
\text { (\%GDP) }\end{array}$} & \multicolumn{2}{|c|}{$\begin{array}{l}\text { Long-Term } \\
\text { External Debt } \\
(\% \text { GDP })\end{array}$} & \multicolumn{2}{|c|}{$\begin{array}{l}\text { Government } \\
\text { Surplus } \\
\text { (\%GDP) }\end{array}$} \\
\hline & $\begin{array}{c}\text { Five } \\
\text { Years } \\
\text { Before }\end{array}$ & $\begin{array}{l}\text { Five } \\
\text { Years } \\
\text { After }{ }^{\text {b }}\end{array}$ & $\begin{array}{c}\text { Five } \\
\text { Years } \\
\text { Before }\end{array}$ & $\begin{array}{c}\text { Five } \\
\text { Years } \\
\text { After }^{\text {b }}\end{array}$ & $\begin{array}{l}\text { Five } \\
\text { Years } \\
\text { Before }\end{array}$ & $\begin{array}{c}\text { Five } \\
\text { Years } \\
\text { After }^{b}\end{array}$ & $\begin{array}{c}\text { Five } \\
\text { Years } \\
\text { Before }\end{array}$ & $\begin{array}{c}\text { Five } \\
\text { Years } \\
\text { After }^{b}\end{array}$ & $\begin{array}{l}\text { Five } \\
\text { Years } \\
\text { Before }\end{array}$ & $\begin{array}{c}\text { Five } \\
\text { Years } \\
\text { After }\end{array}$ & $\begin{array}{c}\text { Five } \\
\text { Years } \\
\text { Before }\end{array}$ & $\begin{array}{c}\text { Five } \\
\text { Years } \\
\text { After }^{b}\end{array}$ & $\begin{array}{c}\text { Five } \\
\text { Years } \\
\text { Before }\end{array}$ & $\begin{array}{c}\text { Five } \\
\text { Years } \\
\text { After }^{b}\end{array}$ & $\begin{array}{l}\text { Five } \\
\text { Years } \\
\text { Before }\end{array}$ & $\begin{array}{l}\text { Five } \\
\text { Years } \\
\text { After" }\end{array}$ & $\begin{array}{c}\text { Five } \\
\text { Years } \\
\text { Before }\end{array}$ & $\begin{array}{c}\text { Five } \\
\text { Years } \\
\text { After }^{\mathrm{b}}\end{array}$ \\
\hline$P$-value ${ }^{\mathrm{d}, \mathrm{f}}$ & & 0.76 & & 0.00 & & 0.62 & & 0.41 & & 0.37 & & 0.58 & & 0.00 & & 0.00 & & 0.75 \\
\hline$P$-value e.r & & 0.85 & & 0.00 & & 0.70 & & 0.29 & & 0.24 & & 0.92 & & 0.02 & & 0.00 & & 0.61 \\
\hline$P$-value ${ }^{\mathrm{d}, \mathrm{k}}$ & & 0.99 & & 0.00 & & 0.66 & & 0.23 & & 0.00 & & 0.00 & & 0.00 & & 0.00 & & 0.00 \\
\hline$P$-valuere & & 0.98 & & 0.00 & & 0.77 & & 0.10 & & 0.00 & & 0.00 & & 0.01 & & 0.00 & & 0.00 \\
\hline
\end{tabular}

Note: Inflation and interest rate calculations exclude Argentina and Brazil. Taiwan is not included in some of the macroeconomic analysis because it is not a member of the IMF and we lack the relevant data. All multivariate regression tests are corrected for group-wise heteroskedasticity and group-wise moving average processes in the residuals. NA $=$ not available.

Deposit rates used for Argentina, Brazil, Mexico, and Turkey

'Probability values based on Newey-West corrected $t$-statistics from the regression

$$
\text { Series }=\mathrm{B} 0+(\text { Indicator for Five Years after Break }) * \mathrm{Bl} \text {. }
$$

"Indicates that the regression was not estimated due to data problems.

${ }^{\mathrm{d}}$ Excludes the Philippines, which has a break down in capital flows.

'Excludes the Philippines and countries with breaks that are not significant.

${ }^{t} t$-statistic significance on a panel estimation with fixed effects of the regression

Series $[i, t]=\mathbf{B} 0[i]+($ Indicator for Five Years after Break $)[i, t] * \mathrm{~B} 1$

${ }^{B} \chi^{2}$ joint test that all of the coefficients are zero in the pooled time series regression with fixed effects

Series $[i, t]=\mathrm{B} 0[i]+($ Country Specific Indicator for Five Years after Break $)[i, t] * \mathrm{BI}[i]$

* Significant at the 10 percent level.

**Significant at the 5 percent level.

*** Significant at the I percent level 
the analysis that excludes only the Philippines, real per capita GDP growth increases from 2.73 percent to 2.93 percent after flow break points. Examining the countries with significant breaks, GDP per capita does not significantly change. On a country-by-country basis, Chile, Colombia, Mexico, and Thailand have significant increases in real GDP per capita. There are increases in Argentina, Greece, India, Malaysia, Portugal, and Taiwan, but they are not significant.

There is a sharp reduction in inflation in many countries. The overall average is skewed by Argentina and Brazil. Excluding these two countries, inflation drops from 21.61 percent to 18.78 percent after the flow break point. Similar results are found for local interest rates.

Capital flow breaks are also associated with changes in trading patterns. Table 6.4 indicates that the size of the trade sector is larger after portfolio flows break. On average the trade sector accounts for 61.4 percent of GDP after a flow break point compared to 50.4 percent before. These results are consistent with a joint process of financial market and economic integration. Indeed, as Feldstein and Horioka (1980) point out, in a world with free capital flows, savings and investment should be delinked and large current account imbalances can be run since they can be feasibly financed. However, the data do not seem to support the notion that larger capital mobility has led to emerging markets running large current account deficits. On average, there is a trade surplus as a percentage of GDP of about 1.4 percent before the capital flows break point, which increases to 2.8 percent on average after the break.

External debt to GDP also significantly decreases on average. While the long-term external debt decreases, the change is not significantly different from zero. With government deficits going down on average as well, it is tempting to conclude that the developing countries have reduced their external debt burden by improving their trade balances and freeing up resources from lower government deficits. In addition, despite the inflowing equity capital, they are on average actually exporting rather than importing capital. This may suggest that developing countries are not relying on more foreign capital at all but have simply replaced debt with equity. Consider the case of Chile in figure 6.1. There is a clear negative correlation between equities and bonds and the largest decrease in external debt of all the countries in our sample. This is consistent with a substitution effect. ${ }^{11}$ Nevertheless, given the large cross-country differences, we should

11. It is well known that many emerging markets have reduced their reliance on commercial bank debt and some, like Chile, have also reduced their reliance on foreign fixed income.

There is some interesting theoretical and empirical work on the various sources of financing. For example, Boyd and Smith's (1996) model suggests that as an economy develops, the aggregate ratio of debt to equity will generally fall, yet debt and equity remain complementary sources for the financing of capital investments. See the empirical work in DemurgüçKunt and Maksimovic (1996). 
caution against such generalized inference. For example, more than half of the average increase in trade surplus to GDP in the postbreak period can be attributed to two European countries: Portugal and Greece.

We also compiled real exchange rate indices for the various countries by dividing the exchange rate in local currency to the dollar by the ratio of the local consumer price index to the U.S. consumer price index. These data are from the International Financial Statistics of the International Monetary Fund. Hence, an increase in the index suggests a real exchange rate depreciation. We find a significant real appreciation of the local currencies in nine of the sixteen countries after equity flow breaks, and a significant drop in only four countries. Overall, foreign capital flows seem to lead to real exchange rate appreciations, as is often claimed. The change is highly statistically significant when we allow for country-specific coefficients in the multivariate regressions.

\subsubsection{Country Risk}

We examine five different measures of country risk: Institutional Investor's Country Credit Rating (IICCR), International Country Risk Guide (ICRG) Economic Risk, ICRG Political Risk, ICRG Financial Risk, and ICRG Composite Risk. The ICRG Composite Risk is a weighted average of the three preceding components (see Erb, Harvey, and Viskanta 1996a, 1996b). A higher country rating means lower risk. These measures are all ex ante. That is, in the case of the IICCR, participants are asked to make an assessment of the future riskiness of a country.

The results in table 6.5 suggest an unambiguous increase in rating across the different measures. For example, the ICRG Composite Risk rating increases in every country except Venezuela. The average rating increases from 61.1 to 69.7 , which is a statistically significant change. Erb, Harvey, and Viskanta (1996a) link expected returns and country ratings. An 8.6point increase in rating would translate into a 2.4 percent decrease in the expected returns. Overall, the message is that capital flow inflows are associated with investor perceptions of lower country risk.

\subsubsection{Portfolio Results}

In a final experiment, we create two equally weighted portfolios. At each month, the first portfolio, which we call the "segmented portfolio," includes the returns of the countries that have not experienced a significant break in the equity capital flows. At each month, the second portfolio, which we call the "integrated portfolio," includes the returns of the country that have already experienced a significant break in the equity capital flows. The number of countries in each portfolio shifts through time as a number of countries move from the segmented portfolio to the integrated portfolio. As such, it is possible that the results could be heavily influenced by one or two countries when there are a small number of countries in the 


\begin{tabular}{|c|c|c|c|c|c|c|c|c|c|c|}
\hline \multirow[b]{2}{*}{ Country } & \multicolumn{2}{|c|}{$\begin{array}{c}\text { Institutional Investor's } \\
\text { Country Credit } \\
\text { Rating }\end{array}$} & \multicolumn{2}{|c|}{$\begin{array}{l}\text { ICRG Economic } \\
\text { Index }\end{array}$} & \multicolumn{2}{|c|}{$\begin{array}{l}\text { ICRG Financial } \\
\text { Index }\end{array}$} & \multicolumn{2}{|c|}{$\begin{array}{l}\text { ICRG Political } \\
\text { Index }\end{array}$} & \multicolumn{2}{|c|}{$\begin{array}{l}\text { ICRG Composite } \\
\text { Index }\end{array}$} \\
\hline & $\begin{array}{c}\text { Five } \\
\text { Years } \\
\text { Before }\end{array}$ & $\begin{array}{l}\text { Five } \\
\text { Years } \\
\text { After }^{a}\end{array}$ & $\begin{array}{c}\text { Five } \\
\text { Years } \\
\text { Before }\end{array}$ & $\begin{array}{l}\text { Five } \\
\text { Years } \\
\text { After }^{\mathrm{a}}\end{array}$ & $\begin{array}{c}\text { Five } \\
\text { Years } \\
\text { Before }\end{array}$ & $\begin{array}{l}\text { Five } \\
\text { Years } \\
\text { After }\end{array}$ & $\begin{array}{l}\text { Five } \\
\text { Years } \\
\text { Before }\end{array}$ & $\begin{array}{l}\text { Five } \\
\text { Years } \\
\text { After }^{\mathbf{a}}\end{array}$ & $\begin{array}{c}\text { Five } \\
\text { Years } \\
\text { Before }\end{array}$ & $\begin{array}{l}\text { Five } \\
\text { Years } \\
\text { After }^{\mathrm{a}}\end{array}$ \\
\hline Argentina & 21.9 & $36.3^{* * *}$ & 21.2 & $32.4 * * *$ & 25.1 & $36.6 * * *$ & 62.4 & $74.0^{* * *}$ & 54.5 & $71.9^{* * *}$ \\
\hline Brazil & 32.7 & $27.5^{* * *}$ & 20.7 & $22.6 * * *$ & 23.9 & $32.2 * * *$ & 63.4 & $66.5^{* * *}$ & 54.1 & $60.8 * * *$ \\
\hline Chile & 28.1 & $36.4 * * *$ & 23.9 & $31.6 * * *$ & 25.6 & $39.1 * * *$ & 45.9 & $62.0^{* * *}$ & 47.9 & $66.5 * * *$ \\
\hline Colombia & 36.4 & $44.4 * * *$ & 33.3 & $34.9 * * *$ & 35.3 & $38.4^{* *}$ & 56.4 & 58.0 & 62.6 & $65.1^{*}$ \\
\hline Greece & 53.1 & $47.5^{* * *}$ & 30.0 & 30.1 & 25.9 & $29.9 * * *$ & 60.7 & $61.8^{*}$ & 58.5 & $61.1 * * *$ \\
\hline India & 47.7 & $51.7 * * *$ & 35.1 & $36.7 * * *$ & 35.0 & $40.2^{* * *}$ & 49.5 & $63.4 * * *$ & 49.4 & $67.0^{* * *}$ \\
\hline Indonesia & 43.7 & 42.6 & 28.8 & $34.9 * * *$ & 27.7 & $36.4 * * *$ & 42.3 & $63.0 * * *$ & 60.6 & $69.8^{* * *}$ \\
\hline Korea & 67.3 & $70.4 * * *$ & 37.7 & $40.6 * * *$ & 47.2 & $46.5^{* * *}$ & 66.8 & $77.3^{* * *}$ & 76.1 & $82.0^{* * *}$ \\
\hline Malaysia & 32.3 & $44.3 * * *$ & 27.4 & $31.2^{* * *}$ & 31.9 & $40.4 * * *$ & 67.9 & 68.7 & 69.8 & $79.8 * * *$ \\
\hline Mexico & 58.4 & $63.7^{* * *}$ & 38.7 & $40.9 * * *$ & 30.8 & $44.2^{* * *}$ & 62.8 & $70.8 * * *$ & 58.2 & $70.5 * * *$ \\
\hline Pakistan & 29.5 & 29.4 & 31.7 & $31.1^{* *}$ & 23.1 & $32.7 * * *$ & 34.7 & $54.2 * * *$ & 44.9 & $59.2 * * *$ \\
\hline Philippines & 22.2 & $27.0 * * *$ & 28.6 & $31.5 * * *$ & 21.6 & $29.1 * * *$ & 42.4 & $48.5 * * *$ & 46.5 & $54.6 * * *$ \\
\hline Portugal & 64.5 & $67.9 * * *$ & 39.3 & $41.5^{* * *}$ & 42.8 & 43.2 & 71.2 & $80.6 * * *$ & 76.8 & $82.7 * * *$ \\
\hline Taiwan & 77.0 & $78.8 * * *$ & 43.5 & 43.5 & 48.2 & 47.3 & 75.2 & $78.6 * * *$ & 83.6 & $85.2 * * *$ \\
\hline Thailand & 53.1 & $60.6 * * *$ & 35.1 & $37.0^{* * *}$ & 29.6 & $41.6^{* * *}$ & 56.9 & $59.5 * * *$ & 61.0 & $69.1 * * *$ \\
\hline Turkey & 38.7 & $43.3^{* * *}$ & 27.8 & 28.0 & 24.1 & $29.6 * * *$ & 52.5 & $57.0^{* *}$ & 52.3 & $57.4 * * *$ \\
\hline Venezuela & 36.0 & $33.6^{* * *}$ & 31.6 & 32.2 & 35.1 & 34.6 & 67.3 & $64.9 * *$ & 67.2 & 66.3 \\
\hline Mean $^{b}$ & 45.02 & 48.65 & 31.61 & 34.33 & 31.96 & 38.31 & 58.48 & 66.25 & 61.09 & 69.65 \\
\hline $\begin{array}{l}P \text {-value } \\
\text { (continued) }\end{array}$ & & 0.26 & & 0.11 & & 0.01 & & 0.02 & & 0.01 \\
\hline
\end{tabular}




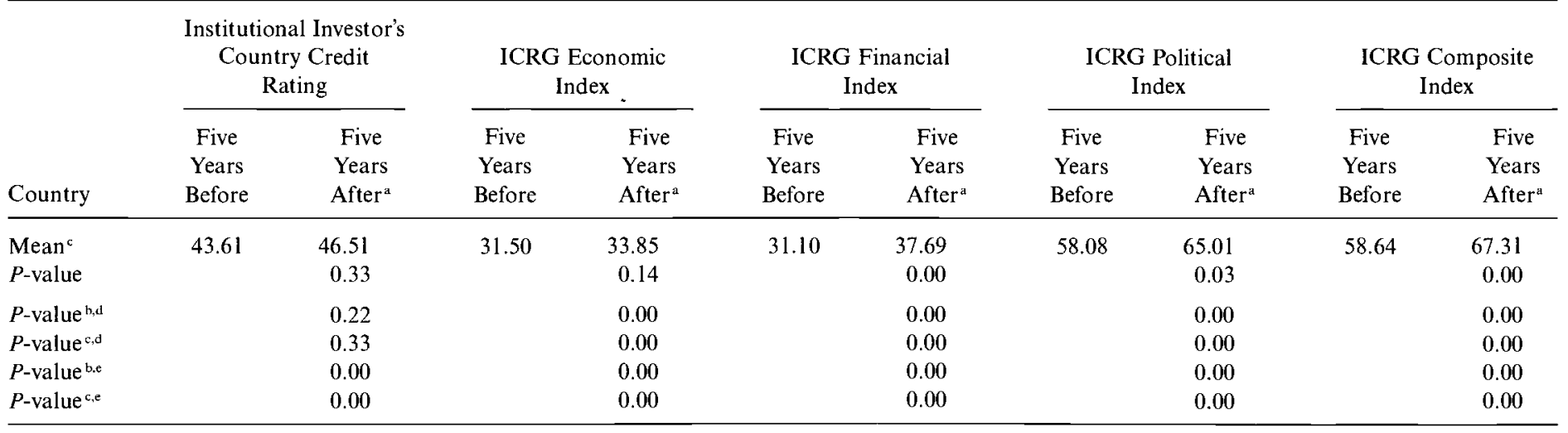

Note: All multivariate regression tests are corrected for group-wise heteroskedasticity and group-wise moving average processes in the residuals.

a Probability values based on Newey-West corrected $t$-statistics from the regression

$$
\text { Series }=\mathrm{B} 0+(\text { Indicator for Five Years after Break }) * \mathrm{~B} 1 .
$$

${ }^{b}$ Excludes the Philippines, which has a break down in capital flows.

'Excludes the Philippines and countries with breaks that are not significant.

${ }^{d} \mathrm{FE}$ indicates the $t$-statistic significance on a panel estimation with fixed effects of the regression

$$
\text { Series }[i, t]=\mathrm{B} 0[i]+(\text { Indicator for Five Years after Break })[i, t] * \mathrm{~B} 1 .
$$

${ }^{\mathrm{e}} \chi^{2}$ joint test that all of the coefficients are zero in the pooled time series regression with fixed effects

$$
\text { Series }[i, t]=\mathrm{B} 0[i]+(\text { Country Specific Indicat or for Five Years after Break })[i, t] * \mathrm{~B} 1[i] \text {. }
$$

* Significant at the 10 percent level.

** Significant at the 5 percent level.

*** Significant at the 1 percent level. 


\begin{tabular}{lcc}
\hline Moment & $\begin{array}{c}\text { Segmented } \\
\text { Portfolio }\end{array}$ & $\begin{array}{c}\text { Integrated } \\
\text { Portfolio }\end{array}$ \\
\hline Significant countries & & \\
$\quad$ Annualized mean \% & 25.88 & 24.13 \\
Annualized volatility \% & 20.73 & 35.16 \\
$\quad$ Correlation with world & 0.132 & 0.355 \\
$\beta$ with world & 0.174 & 0.771 \\
All countries & & \\
Annualized mean \% & 20.78 & 25.52 \\
Annualized volatility \% & 18.70 & 33.01 \\
Correlation with world & 0.365 & 0.320 \\
$\beta$ with world & 0.423 & 0.652 \\
\hline
\end{tabular}

Note: Significant countries include all countries in the analysis except for Chile, Turkey, Malaysia, Taiwan, Indonesia, and Portugal. The Philippines is always excluded.

portfolio. To address this problem, we restrict the sample period to January 1987-September 1994.

The portfolio results are contained in table 6.6. Consistent with our analysis of the cost of capital and our tests on the ex post returns, there is little difference in the ex post observed returns (25.9 percent compared to 24.1 percent on an annual basis for the significant countries). We also find evidence of higher volatility. In the segmented portfolio, the average annualized volatility is 20.7 percent, whereas in the integrated portfolio the volatility is 35.2 percent. The volatility analysis contrasts with the inconclusive results in the ex post volatility analyzed in table 6.2.

We also calculated the correlations and $\beta$ s of the two portfolios with world returns. The correlation with the world portfolio increases from 0.13 to 0.36 moving from the segmented to the integrated portfolio. We also find that the $\beta$ increases from 0.17 to 0.77 . The increase in correlation is consistent with integrated markets being relatively more affected by world information than segmented markets.

\subsection{Conclusions}

The idea of our paper is that patterns in capital flows can reveal information about market liberalizations. In a segmented capital market, there are unlikely to be significant foreign capital flows. An effective capital market liberalization may be associated with significant new foreign capital flows. Our starting point is to identify breaks in equity capital flows. In sixteen of the seventeen countries we examine, such a break is associated with an increase in net capital flows. We then compare measures of both the financial system and the economy in the prebreak and postbreak regimes. 
Ours is the first paper to compare and contrast the behavior of both equity and bond capital flows. For many countries, the patterns of equity and bond flows are very similar. In a few countries, it seems that bond flows precede equity flows.

We find that expected returns decrease after significant breaks in capital flows. In addition, risk decreases, at least as measured by country rating, and the correlation of equity returns with the world market is higher. This seems consistent with a "one-time" portfolio adjustment associated with the movement from segmented to integrated markets. It does not seem to be consistent with the "return chasing" hypothesis postulated by Bohn and Tesar (1996).

In addition, we find that the increase in capital flows is associated with marginally higher per capita GDP, a larger trade sector, less long-term country debt, lower inflation, and lower foreign exchange rate volatility.

Although not all of these changes are statistically significant, the general picture is one that contradicts the view that foreign portfolio investors are detrimental to a developing country's economy. Of course, our methods do not allow us to distinguish between the scenario where foreign equity investment is responsible for the improved macroeconomic and financial outlook and the scenario where it is simply attracted by the prospect of these improvements. Nevertheless, our suggestive findings of lower expected returns and risk and higher loadings on world factors are consistent with international investors rebalancing their portfolios in response to a wider opportunity set (see also Bohn and Tesar 1996). If this is the case, policy makers across the world would be well advised to create an environment that attracts, rather than repels, foreign portfolio investors.

\section{References}

Aggarwal, Reena, Carla Inclan, and Ricardo Leal. 1999. Volatility in emerging stock markets. Journal of Financial and Quantitative Analysis 34 (1): 33-55.

Bai, Jushan, Robin L. Lumsdaine, and James H. Stock. 1998. Testing for and dating breaks in stationary and nonstationary multivariate time series. Review of Economic Studies 65 (3): 395-432.

Bartolini, Leonardo, and Allan Drazen. 1996. Capital account liberalization as a signal. NBER Working Paper no. 5925. Cambridge, Mass.: National Bureau of Economic Research.

Bekaert, Geert. 1995. Market integration and investment barriers in emerging equity markets. World Bank Economic Review 9 (1): 75-107.

Bekaert, Geert, and Campbell R. Harvey. 1995. Time-varying world market integration. Journal of Finance 50:403-44.

43:29-78. 
1998. Capital markets: An engine for economic growth. Brown Journal of World Affairs 5 (1): 33-58.

.2000. Foreign speculators and emerging equity markets. Journal of Finance 55, no. 2 (April): 565-613.

Bekaert, Geert, Campbell R. Harvey, and Robin Lumsdaine. 1999. Dating the integration of world capital markets. Unpublished working notes, Stanford University and Duke University.

Bekaert, Geert, and Michael S. Urias. 1996. Diversification, integration and emerging market closed-end funds. Journal of Finance 51:835-70.

Bohn, H., and L. Tesar. 1996. U.S. equity investment in foreign markets: Portfolio rebalancing or return chasing? American Economic Review 86, no. 2 (May): $77-81$.

Boyd, J., and B. Smith. 1996. The coevolution of the real and financial sectors in the growth process. World Bank Economic Review 10 (May): 371-96.

Claessens, S., M. Dooley, and A. Warner. 1993. Portfolio capital flows: Hot or cool? In Portfolio investment in developing countries, ed. S. Claessens and S. Gooptu, 18-44. Washington, D.C.: World Bank.

Clark, J. M., and E. Berko. 1997. Foreign investment fluctuations and emerging market stock returns: The case of Mexico. Unpublished working paper. New York: Federal Reserve Bank.

Demurgüç-Kunt, Asli, and V. Maksimovic. 1996. Stock market development and financing choices of firms. World Bank Economic Review 10 (May): 341-69.

De Santis, Giorgio, and Selahattin İmrohoroğlu. 1996. Stock returns and volatility in emerging financial markets. Unpublished working paper, University of Southern California, Los Angeles.

Erb, Claude B., Campbell R. Harvey, and Tadas E. Viskanta. 1996a. Expected returns and volatility in 135 countries. Journal of Portfolio Management 22, no. 3 (spring): 46-58.

. 1996b. Political risk, economic risk and financial risk. Financial Analysts Journal 52, no. 6 (November/December): 29-46.

Feldstein, M., and C. Horioka. 1980. Domestic saving and international capital flows. Economic Journal 90:314-29.

Glosten, Lawrence R., Ravi Jagannathan, and David E. Runkle. 1993. On the relation between the expected value and the volatility of the nominal excess return on stocks. Journal of Finance 48:1779-1802.

Harris, L., and E. Gurel. 1986. Price and volume effects associated with changes in the S\&P 500 list: New evidence for the existence of price pressure. Journal of Finance 41:815-29.

Harvey, Campbell R. 1991. The world price of covariance risk. Journal of Finance 46:111-57.

Henry, Peter Blair. 2000. Equity prices, stock market liberalization, and investment. Journal of Financial Economics, forthcoming.

Howell, Michael. 1993. Institutional investors and emerging stock markets. In Portfolio investment in developing countries, ed. S. Claessens and S. Gooptu. Washington, D.C.: World Bank.

Howell, Michael, and Angela Cozzini. 1991. International equity flows-Games without frontiers: Global equity markets in the 1990s. International Equity Research, Salomon Brothers. 1992. International equity flows. London: Barings Securities.

Kang, Jun-Koo, and René M. Stulz. 1997. Why is there a home bias? An analysis of foreign portfolio equity ownership in Japan. Journal of Financial Economics 48, no. 1 (October): $3-28$. 
Kester, Annie Y., et al. 1994. Following the money: US finance in the world economy. Washington, D.C.: National Academy of the Sciences.

Kim, E. Hand, and Vijay Singal. 2000. Stock market openings: Experience of emerging economies. Journal of Business, forthcoming.

King, Robert, and Ross Levine. 1993a. Finance and growth: Schumpeter might be right. Quarterly Journal of Economics 111:639-71.

. 1993b. Finance, entrepreneurship, and growth. Journal of Monetary Economics 32 (3): 513-42.

Korajczyk, Robert A. 1996. A measure of stock market integration for developed and emerging markets. World Bank Economic Review 10:267-90.

Krugman, Paul. 1993. International finance and economic development. In $\mathrm{Fi}$ nance and development: Issues and experience, ed. Alberto Giovannini, 11-23. Cambridge: Cambridge University Press.

Levine, Ross, and Sara Zervos. Stock market development and long-run growth. World Bank Economic Review 10:323-40.

Mathieson, Donald J., and Liliana Rojaz-Suarez. 1992. Liberalization of the capital account: Experiences and issues. Unpublished working paper. Washington, D.C.: International Monetary Fund.

Obstfeld, Maurice. 1994. Risk taking, global diversification and growth. American Economic Review 84:1310-29.

Rajan, Raghuram G., and Luigi Zingales. 1997. Financial dependence and growth. Unpublished working paper. Graduate School of Business, University of Chicago.

Richards, Anthony J. 1996. Volatility and predictability in national markets: How do emerging and mature markets differ? IMF Staff Papers 43 (3).

Sachs, J., and A. Warner. 1995. Economic reform and the process of global integration. Brookings Papers on Economic Activity, no. 1: 1-118.

Shleifer, A. 1986. Do demand curves for stocks slope down? Journal of Finance 41:579.

Stulz, R. M. 1999. International portfolio flows and security markets. In International capital flows, ed. Martin Feldstein, 257-93. Chicago: University of Chicago Préss.

Tesar, L., and I. Werner. 1994. International equity transactions and U.S. portfolio choice. In The internationalization of equity markets, ed. J. Frankel, 185-215. Chicago: University of Chicago Press.

1995a. U.S. equity investment in emerging stock markets. World Bank Economic Review 9 (1): 109-30.

- 1995b. Home bias and high turnover. Journal of International Money and Finance 14 (4): 467-92.

Warther, V. A. 1995. Aggregate mutual fund flows and security returns. Journal of Economics 39:209-35. 